\title{
Revealing the Influence of Secondary Metals on Redox- Active Palladium Complexes
}

\author{
[a] R. R. Golwankar, Dr. A. Kumar, Dr. V. W. Day, and Prof. J. D. Blakemore \\ Department of Chemistry \\ University of Kansas \\ 1567 Irving Hill Road, Lawrence, Kansas 66045, USA \\ E-mail: blakemore@ku.edu \\ $\dagger \quad$ Current address: Department of Chemistry, University of Pennsylvania, \\ Philadelphia, Pennsylvania 19104, United States
}

Riddhi R. Golwankar, ${ }^{[a]}$ Amit Kumar, ${ }^{[a], \dagger}$ Victor W. Day,${ }^{[a]}$ and James D. Blakemore ${ }^{*[a]}$

\begin{abstract}
Incorporation of redox-inactive metals into redox-active complexes and catalysts attracts attention for engendering new reactivity modes, but this strategy has not been extensively investigated beyond the first-row of the transition metals. Here, the isolation and characterization of the first series of heterobimetallic complexes of palladium with mono-, di-, and tri-valent redox-inactive metal ions are reported. A Reinhoudt-type heteroditopic ligand with a salen-derived $\left[\mathrm{N}_{2}, \mathrm{O}_{2}\right]$ binding site for Pd and a crown-ether-derived $\left[\mathrm{O}_{6}\right]$ site has been used to prepare isolable adducts of the Lewis acidic redox-inactive metal ions $\left(\mathbf{M}^{\mathrm{n}+}\right)$. Comprehensive data from single-crystal X-ray diffraction analysis reveal distinctive trends in the structural properties of the heterobimetallic species, including an uncommon dependence of the $\mathbf{P d} \bullet \cdot \mathbf{M}$ distance on Lewis acidity. The reorganization energy associated with reduction of the heterobimetallic species is strongly modulated by Lewis acidity, with the slowest heterogeneous electron transfer kinetics associated with the strongest incorporated Lewis acids. This hitherto unexplored reorganization energy penalty for electron transfer contrasts with prior thermodynamic studies, revealing that kinetic parameters should be considered in studies of reactivity involving heterobimetallic species.
\end{abstract}

\section{Introduction}

The tuning of metal complexes through the addition or incorporation of secondary metal ions has emerged as an attractive strategy for engendering controllable chemical properties and new reactivity patterns. ${ }^{[1]}$ For example, redox-inactive ions have been very effectively utilized to increase the oxidizing power of a variety of metal-oxygen species, ${ }^{[2]}$ enabling activation of substrates that are otherwise resistant to oxidation. In earlier work, Lau and Lee showed that the reactivity of classic inorganic oxidants $\left(\mathrm{MnO}_{4}^{-}, \mathrm{Cr}_{2} \mathrm{O}_{7}{ }^{2-}\right)$ could be modulated with redox-inactive metal ions. ${ }^{[3]}$ These observations, among many others, generated significant interest in molecular systems that leverage such heterometallic effects.

Advances in synthetic chemistry have enabled assembly and isolation of structures containing multiple metals, providing welldefined structures that give insight into the specific interactions responsible for the observed tuning effects. Agapie's work with oxo-bridged multimetallic clusters is a notable example of such synthetic chemistry, as it provided insight into the role of redoxinactive cations like $\mathrm{Ca}^{2+}$ in tuning the redox chemistry of such clusters. ${ }^{[4]}$ Such work is inspired by the presence of an essential calcium ion in the Oxygen Evolving Complex (OEC) of Photosystem II, as the calcium ion can serve to modulate the reduction potential of the nearby manganese ions and thereby enable water oxidation to occur. ${ }^{[5]}$ The redox chemistry and catalytic properties of numerous first-row transition metal complexes have been modulated with secondary metal cations in related ways ${ }^{[6]}$ confirming the usefulness of this approach to tuning the properties of metal complexes.

Heteroditopic ligand frameworks containing binding sites for both redox-active and redox-inactive metals can be used to study heterometallic effects as well. One class of such ligand frameworks were developed originally by Reinhoudt ${ }^{[7]}$ and elaborated upon by Vigato and others, ${ }^{[8]}$ and feature a $\left[\mathrm{N}_{2}, \mathrm{O}_{2}\right]$ Schiff-base salen- or salophen-like site placed in close proximity to an [O6] crown-ether-like site (see Chart 1). Heterobimetallic work with these ligands was initiated by Horwitz and co-workers, who examined the reactivity of manganese bound in the $\left[N_{2}, O_{2}\right]$ site that could be triggered by the addition of secondary metals that would presumably bind in the $\left[\mathrm{O}_{6}\right]$ site..$^{[9]}$ The Matsunaga and Shibasaki groups were also active early on in this field, developing diverse families of dinuclear Schiff-base compounds for use as catalysts. ${ }^{[10]}$ More recently, Yang and co-workers have used a convergent synthetic approach to prepare and isolate heterobimetallic complexes of $\mathrm{Co}(\mathrm{II})$ and $\mathrm{Ni}(\mathrm{II})$ with such ligands, ${ }^{[11]}$ and Williams and co-workers have developed several classes of complexes with related ligands as catalysts for copolymerization reactions. ${ }^{[12]}$ 

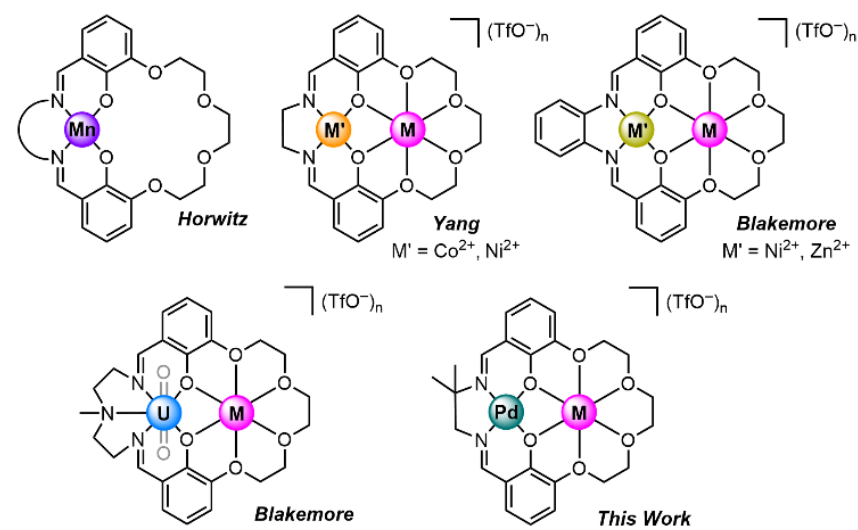

This Work
$\mathrm{M}=\mathrm{K}^{+}, \mathrm{Na}^{+}, \mathrm{Ca}^{2+}, \mathrm{Sr}^{2+}, \mathrm{La}^{3+}, \mathrm{Y}^{3+}, \mathrm{Lu}^{3+}$

Chart 1. Heterobimetallic complexes supported by Reinhoudt-type heteroditopic ligand frameworks.

In our own work, we have become interested in the chemical and electrochemical properties of heterobimetallic complexes of heavier elements. We have prepared a series of heterobimetallic and macrocyclic complexes containing the uranyl $\left(\mathrm{UO}_{2}{ }^{2+}\right)$ ion in order to understand the influence of incorporated redox-inactive metals on the thermodynamics and kinetics of electron transfer to uranium. ${ }^{[13]}$ Building on related work with $\mathrm{Ni}(\mathrm{II})$ and $\mathrm{Zn}(\mathrm{II})$ complexes, ${ }^{[14,15]}$ we have found that compounds incorporating the strongly Lewis acidic trivalent cations undergo the greatest changes in their redox chemistry, similar to findings from chemical work with actinide elements. ${ }^{[16]}$ Thus, rational tuning of the redox-active heavy elements appears to be an appealing strategy to promote new reactivity with these challenging elements.

In the context of this work, we examined the literature and were surprised to find that tuning of second- and third-row transition metal complexes with Lewis acidic, redox-inactive metals has received little attention in comparison to the large body of work on the tuning of first-row transition metal species. Multi-component systems for tuning of ruthenium, ${ }^{[17]}$ osmium, ${ }^{[18]}$ rhodium, ${ }^{[19]}$ and palladium ${ }^{[20]}$ have been reported, as have a few examples of tuning in iridium ${ }^{[21]}$, palladium ${ }^{[22]}$, and rhenium ${ }^{[23]}$ complexes with mono- and di-valent redox-inactive metals. However, no work has examined the tuning that could be accessible by incorporation of a full range of mono-, di-, and tri-valent Lewis acidic ions into well-defined heterobimetallic complexes of a second- or third-row metal. Considering our successful prior work on tuning of the redox chemistry of the uranyl ion, ${ }^{[13]}$ we hypothesized that the modularity of this chemistry might enable tuning of complexes of palladium, a second-row transition metal noted for its importance in catalysis.

Here, we report the synthesis, isolation, and study of heterobimetallic palladium complexes built upon a Reinhoudt-type ligand framework. Incorporation of a broad range of Lewis acidic cations $\left(\mathrm{M}^{\mathrm{n}}=\mathrm{K}^{+}, \mathrm{Na}^{+}, \mathrm{Sr}^{2+}, \mathrm{Ca}^{2+}, \mathrm{La}^{3+}, \mathrm{Y}^{3+}, \mathrm{Lu}^{3+}\right)$ has been carried out and reveals that the electronic properties of the complexes can be tuned with the secondary metals. Trends in the electronic and electrochemical properties can be described and quantified by the $p K_{a}$ values of the metal-aqua complexes of the incorporated redox-inactive cations, spanning a wide range of acidity with $\mathrm{pK}$ a values of 16.0 for $\mathrm{K}^{+}$to 8.3 for $\mathrm{Y}^{3+}$. ${ }^{[24]}$ Singlecrystal X-ray diffraction data confirm assembly of homologous $\left[\mathrm{Pd}^{\prime \prime}\left(\mu_{2}-\mathrm{O}_{\mathrm{Ar}}\right)_{2} \mathrm{M}^{\mathrm{n}+}\right]$ cores in all cases, providing the first comprehensive series of complexes with mono-, di-, and tri-valent metals paired with a second-row transition metal. UV-visible absorption spectra and electrochemistry data reveal the LUMO of the complexes is ligand-based, enabling exploration of reduction processes that can be assigned as ligand-centered on the basis of trends in the data and comparisons with literature. Quantification of reduction potential and reorganization energy trends suggest key differences in the tuning of the palladium complexes in comparison with their first-row analogues, providing new insight into the wide scope of tuning accessible with Lewis acidic metals. 


\section{Results}

Our group has previously utilized a divergent synthetic strategy for the preparation of heterobimetallic complexes. We have found that this strategy can be successfully applied to the preparation of $\mathrm{Ni}$ (II) complexes as well as $\mathrm{Zn}$ (II) complexes of a common Reinhoudt-type salophen-based ligand framework. ${ }^{[14,15]}$ The approach is advantageous in that a common monometallic precursor complex can be readily treated with triflate salts of redox-inactive metals in order to access diverse families of complexes, and thus we worked to apply this strategy here. In the prior work, $\mathrm{Ba}^{2+}$-templated macrocyclization was readily achieved by treatment of a linear dialdehyde precursor (derived from triethylene glycol ditosylate and 2,3dihydoxybenzaldehyde) with o-phenylenediamine. However, in the work described here, a more specialized diamine reagent was required, namely 1,1-dimethyl-1,2-ethylenediamine; this reagent favors the macrocyclization reaction that yields the key synthon $\left[\mathrm{H}_{2}, \mathrm{Ba}\right]$ (see Scheme 1). The dimethylation favors a syn disposition of the amine groups, a consequence of the Thorpe-Ingold effect, ${ }^{[25]}$ enabling generation of the desired macrocycle. $\left[\mathrm{H}_{2}, \mathrm{Ba}\right.$ ] has been discussed in the literature previously, ${ }^{[7 a]}$ but has not been isolated in prior work. We have found that this compound is well behaved and can be readily isolated as a solid for use at a later time. Single-crystals of $\left[\mathrm{H}_{2}, \mathrm{Ba}\right]$ suitable for $\mathrm{X}$-ray diffraction analysis were also grown, confirming the formulation of this complex and the presence of the desired diamine bridge in the final structure of the isolated material (see SI, Figures S83-S86).

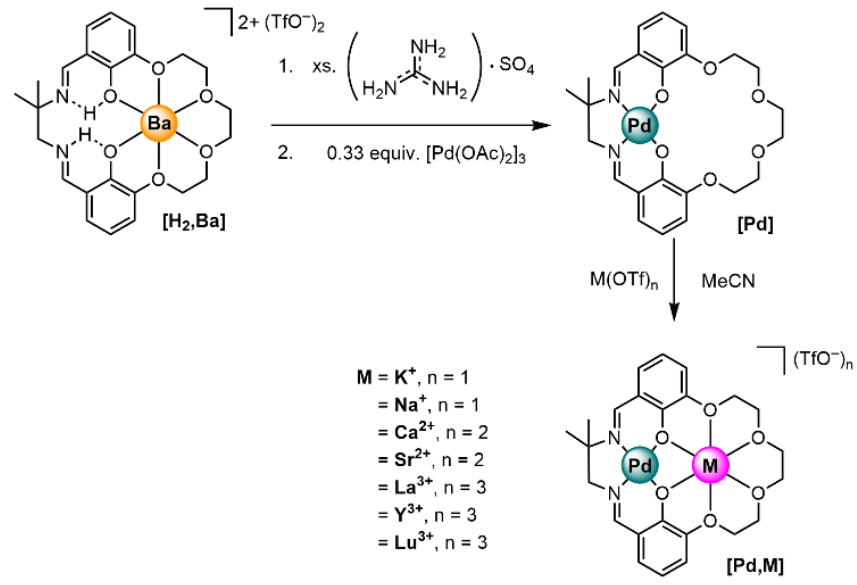

Scheme 1. Synthesis strategy for preparation of heterobimetallic palladium complexes.

The monometallic complex [Pd] could be readily prepared by treatment of 1 equiv. of $\left[\mathrm{H}_{2}, \mathrm{Ba}\right.$ ] first with guanidium sulfate to remove the templating barium and subsequently with 0.33 equiv. of the palladium acetate trimer, $\left[\mathrm{Pd}(\mathrm{OAc})_{2}\right]_{3}$. Much like the readily-protonolyzed precursors $\mathrm{Ni}(\mathrm{OAc})_{2}$ and $\mathrm{Zn}(\mathrm{OAc})_{2}$ used in our prior work, $\left[\mathrm{Pd}(\mathrm{OAc})_{2}\right]_{3}$ is effective for incorporation of palladium into the salen-like site of the heteroditopic ligand. Single crystals of [Pd] suitable for XRD analysis were grown by vapor diffusion of $\mathrm{Et}_{2} \mathrm{O}$ into a solution of the compound in $\mathrm{CH}_{2} \mathrm{Cl}_{2}$. As predicted from nuclear magnetic resonance (NMR) spectra (see SI, Figures S9-S13), the palladium center adopts a square-planar geometry, coordinating to the salen-like site and not interacting directly with the O-atoms of the ether atoms in the crown-ether-like site (see Figure 1). The complex is overall neutral with no co-crystallized solvents or other components in the data, revealing that the crown-ether-like site is open and available to bind Lewis acidic secondary metals.

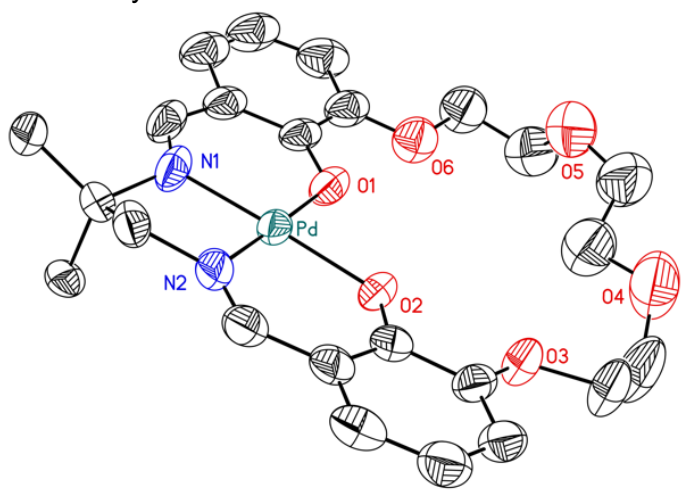

Figure 1. Solid-state structure (XRD) of [Pd]. Hydrogen atoms are omitted for clarity. Displacement ellipsoids shown at the $50 \%$ probability level. 
With $[P d]$ in hand, heterobimetallic complexes of the form $[\mathrm{Pd}, \mathrm{M}]$ could be synthesized by reaction with corresponding metal triflate salts. Specifically, 1 equiv. of metal triflate salt was reacted with [Pd] to obtain a 1:1 bimetallic complex with high yields in each case. As in our previous work, we chose to use the $\mathrm{p} K_{\mathrm{a}}$ values of the metal-aqua complexes of the incorporated metal ions as a measure of their Lewis acidities, an approach successfully taken in a number of areas in the literature. ${ }^{[13,14,15]}$ We elected to use potassium ( $\mathrm{p} K_{\mathrm{a}}=16.0$ ), sodium (14.8), strontium (13.2), calcium (12.6), lanthanum (9.1), yttrium (8.3), and lutetium (7.9) as the redox-inactive metals for the present work. ${ }^{1} \mathrm{H},{ }^{13} \mathrm{C}$, and ${ }^{19} \mathrm{~F} \mathrm{NMR}$ studies (see SI, Figures S14-S43) and elemental analyses of all the materials were successfully performed, validating the formation and clean isolation of the targeted compounds (see the SI and Experimental Section for details). In the organic solvents used here, the Pd(II) ion remains bound in the $\left[N_{2}, \mathrm{O}_{2}\right]$ site in all case, while the redox-inactive metal cations are bound in the [ $\left.\mathrm{O}_{6}\right]$ site, as evidenced by ${ }^{1} \mathrm{H}$ NMR spectra. The downfield resonances corresponding to the imine protons of each complex are particularly diagnostic of coordination of the redox-inactive metal ions, revealing more downfield shifts for the derivatives incorporating stronger Lewis acids (see SI, Figure S49). No evidence of metal-ion scrambling between the two binding sites was observed in our work, indicating that our ligand scaffold can support orthogonal metalation and divergent synthesis.

$\mathrm{XRD}$ analysis of the heterobimetallic complexes containing $\mathrm{K}^{+}, \mathrm{Na}^{+}, \mathrm{Sr}^{2+}, \mathrm{Ca}^{2+}, \mathrm{Y}^{3+}$, and $\mathrm{Lu}^{3+}$ confirmed assembly of the desired $\left[\mathrm{Pd}^{\prime \prime}\left(\mu_{2}-\mathrm{O}_{\mathrm{Ar}}\right)_{2} \mathrm{M}^{\mathrm{n}+}\right]$ cores in each case. For the structures containing $\mathrm{K}^{+}, \mathrm{Sr}^{2+}, \mathrm{Y}^{3+}$, and $\mathrm{Lu}^{3+}$, the data obtained were of high resolution and suitable for metrical comparisons between the structures. On the other hand, the data for [Pd,Na] and [Pd,Ca] were significantly impacted by solid-state features that decreased the quality of the data. As a result, the findings for [Pd,Na] and $[\mathbf{P d}, \mathbf{C a}]$ were used solely to confirm the connectivities of the complexes, which confirmed the expected structures in both cases. Structural data for the high-quality structures are summarized in Table 1, and details for all the structures are available in the SI Section on pp. S49-S83. Please refer to the Experimental Section for information about solvent systems utilized to grow the single-crystals suitable for XRD analysis. The $\mathrm{Pd}(\mathrm{II})$ ion remains strictly square planar in all of the heterobimetallic complexes, with values of the conventional $\tau_{4}$ geometry index ${ }^{[27]}$ that span a narrow range from $0.005-0.036$, comparing well with the value of 0.026 for the parent monometallic complex [Pd].

$[\mathbf{P d}, \mathbf{N a}]$ and $[\mathbf{P d}, \mathbf{K}]$ feature redox-inactive cations with coordination numbers of 7 and 8 , a trend consistent with the smaller ionic radius of $\mathrm{Na}^{+}$than $\mathrm{K}^{+} .{ }^{[26]}$ In the structure of $[\mathbf{P d}, \mathbf{K}]$, the coordination number is greater due to the triflate counterion adopting the $\kappa^{2}$ binding mode (see Figure 2, upper structure); this contrasts with the behavior of the bound triflates in the structure of [Pd,Na], in which these ions exhibit the $\kappa^{1}$ mode (see SI, Figures S91-S96). This conclusion is supported by the data for $[\mathbf{P d}, \mathrm{Ca}]$ and $[\mathrm{Pd}, \mathrm{Sr}]$ in that the structure for the smaller $\mathrm{Ca}^{2+}$ displays two $\kappa^{1}$-triflate ions and a CN of 8 (see $\mathrm{SI}$, Figures S101-S105), whereas [Pd,Sr] displays one $\kappa^{1}$-triflate and one $\kappa^{2}$-triflate (Figure 2, lower structure). Notably, the structures of $[\mathbf{P d}, \mathrm{Y}]$ and $[\mathbf{P d}, \mathbf{L u}]$ are isomorphous, revealing the $\mathrm{Y}^{3+}$ and $\mathrm{Lu}^{3+}$ ions to be 9 -coordinate and bound by three $\kappa^{1}$-triflates in both cases (see Figure 3). However, one of the $\kappa^{1}$-triflates is disordered in the structure of the $\mathrm{Y}^{3+}$ complex, consistent with greater geometric flexibility in the coordination sphere induced by the presence of the larger $\mathrm{Y}^{3+}$ ion; the triflate disorder is shown in Figure S106 in the Supporting Information. The role of the larger $\mathrm{Y}^{3+}$ ion in the structure was confirmed by comparison of the cell volumes for $[\mathbf{P d}, \mathbf{Y}]$ and $[\mathbf{P d}, \mathbf{L u}]$; the volume of $4178.9(2) \AA^{3}$ for $[\mathbf{P d}, \mathbf{Y}]$ is notably larger than that for $[\mathbf{P d}, \mathbf{L u}]$ at $4152.0(2)$ $\AA^{3}$. 

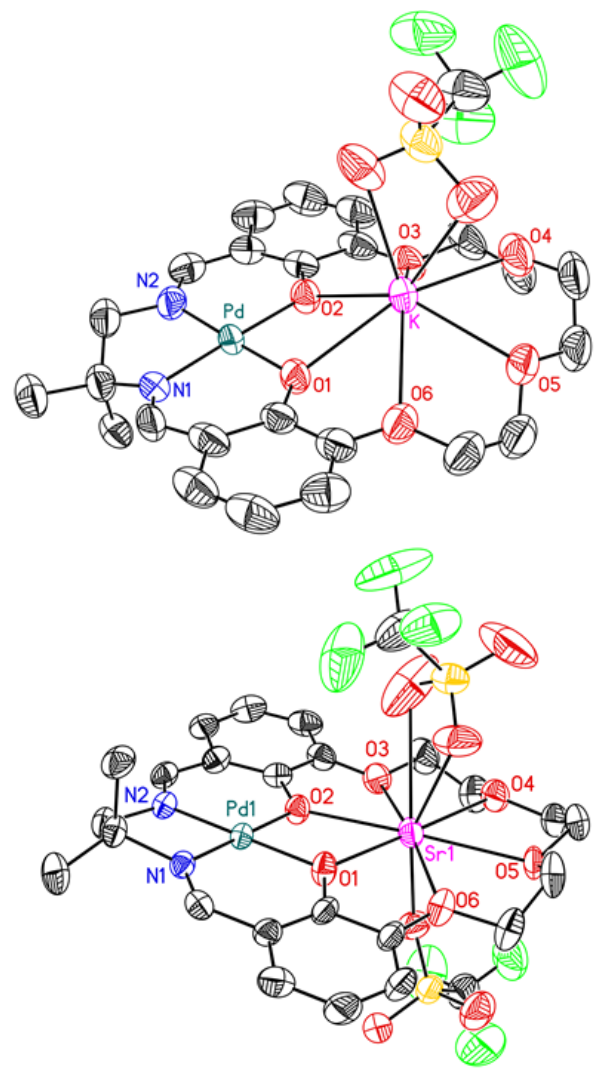

Figure 2. Solid-state structure (XRD) of [Pd,K] and [Pd,Sr]. Hydrogen atoms and a co-crystallized $\mathrm{MeOH}$ solvent molecule in the structure of [Pd,Sr] are omitted for clarity. Displacement ellipsoids shown at the $50 \%$ probability level. 
Table 1. Comparison of $\left[\mathrm{M}\left(\mathrm{H}_{2} \mathrm{O}\right)_{\mathrm{m}}\right]^{\mathrm{n}+}$ complexes with $\mathrm{p} K_{\mathrm{a}}$ values, selected bond lengths, interatomic distances, and root mean square deviations $(\omega)$.

\begin{tabular}{|c|c|c|c|c|c|c|c|}
\hline & {$\left[\mathrm{H}_{2} \mathrm{Ba}\right]$} & {$[\mathrm{Pd}]$} & {$[\mathrm{Pd}, \mathrm{K}]$} & {$[\mathrm{Pd}, \mathrm{Sr}]$} & {$[\mathrm{Pd}, \mathrm{Y}]$} & {$[\mathrm{Pd}, \mathrm{Lu}]$} & {$\left[\mathrm{Zn}_{2}\right]$} \\
\hline $\mathrm{p} K_{\mathrm{a}}$ of $\left[\mathrm{M}\left(\mathrm{H}_{2} \mathrm{O}\right)_{\mathrm{m}}\right]^{\mathrm{n+}}$ & 13.4 & - & 16.0 & 13.2 & 8.3 & 7.9 & - \\
\hline 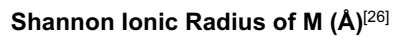 & - & - & 1.51 & 1.31 & 1.075 & 1.032 & - \\
\hline Coordination Number of $\mathbf{M}$ & - & - & 8 & 9 & 9 & 9 & \\
\hline Pd-N1 (A) & - & $1.956(4)$ & $1.934(5)$ & $1.951(4)$ & $1.956(7)$ & $1.937(5)$ & - \\
\hline Pd-N2 (A) & - & $1.959(5)$ & $1.970(6)$ & $1.938(5)$ & $1.934(7)$ & $1.950(6)$ & - \\
\hline $\mathrm{Pd}-01(\mathrm{~A})$ & - & $1.982(4)$ & $1.982(4)$ & $1.991(6)$ & $1.990(5)$ & $1.993(4)$ & - \\
\hline $\mathrm{Pd}-\mathrm{O} 2(\AA)$ & - & 1.994(3) & $1.972(4)$ & $1.976(6)$ & $1.978(5)$ & $1.963(4)$ & - \\
\hline $01 \bullet \cdot 02(\AA)$ & $3.006(6)$ & $2.727(5)$ & $2.695(5)$ & $2.666(9)$ & $2.584(8)$ & $2.562(6)$ & $2.933(3)$ \\
\hline N1 $\cdots+N 2(A)$ & $2.858(8)$ & $2.624(8)$ & $2.637(8)$ & $2.616(9)$ & $2.624(12)$ & $2.633(8)$ & $2.622(12)$ \\
\hline N1॰•01 (A) & $2.570(7)$ & $2.908(7)$ & $2.895(7)$ & $2.914(7)$ & $2.936(10)$ & $2.942(7)$ & $2.883(10)$ \\
\hline $\mathrm{N} 2 \bullet \bullet \bullet \mathrm{O} 2(\mathrm{~A})$ & $2.567(7)$ & $2.892(6)$ & $2.879(6)$ & $2.902(7)$ & $2.947(10)$ & $2.926(7)$ & $2.699(8)$ \\
\hline$P d \bullet \bullet M(A)$ & - & - & $3.74(1)$ & $3.627(2)$ & $3.434(1)$ & $3.404(1)$ & - \\
\hline$T_{4}^{[a]}$ & - & 0.026 & 0.036 & 0.005 & 0.028 & 0.033 & 0.390 \\
\hline $\boldsymbol{\omega}_{\text {crown }^{[b]}}$ & 0.232 & 0.277 & 0.248 & 0.079 & 0.464 & 0.486 & 0.134 \\
\hline $\boldsymbol{\omega}_{\text {salmen }}{ }^{[c]}$ & 0.039 & 0.022 & 0.041 & 0.001 & 0.012 & 0.001 & 0.052 \\
\hline
\end{tabular}

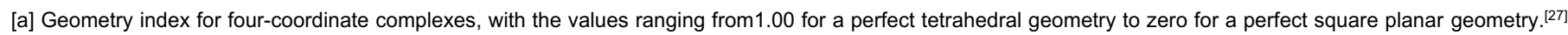

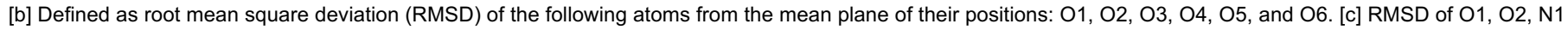
and N2. Atom labels are consistent with those given in the raw crystallographic data (see Supporting Information) 
Contrasting with our prior work on $[\mathrm{Ni}, \mathrm{Y}]$ and $[\mathrm{Zn}, \mathrm{Y}]$ heterobimetallic complexes, the structure of $[\mathrm{Pd}, \mathrm{Y}]$ reveals that $\mathrm{O}$-atom(s) of the triflate counterions bind solely to $\mathrm{Y}^{3+}$ and do not interact with the $\mathrm{Pd}(\mathrm{II})$ center. In [Ni,Y] and [Zn, Y], a single triflate counterion was found to bridge between the two metals with Ni-Otriflate and $\mathrm{Zn}-\mathrm{O}_{\text {triflate }}$ distances of $2.786 \AA$ and $2.094(3) \AA$, respectively. The observation of strictly four-coordinate $\mathrm{Pd}(\mathrm{II})$ is consistent, however, with the anticipated greater ligand field stabilization energy of $\mathrm{Pd}(\mathrm{II})$ vs. $\mathrm{Ni}(\mathrm{II})$ or $\mathrm{Zn}(\mathrm{II})$, a feature that should give rise to a higher-lying $d_{z}{ }^{2} \sigma^{*}$ orbital that prefers to be unfilled in these square planar complexes. A tendency to avoid additional bridging ligands beyond the phenoxide O-donors is thus a distinction for the $\mathrm{Pd}(\mathrm{II})$ complexes studied here.

With this comprehensive set of crystallographic data in hand, trends in the influences of the secondary Lewis acidic metals on the structures of the $\mathrm{Pd}(\mathrm{II})$ complexes can be observed. First, the $\mathrm{Pd} \bullet \bullet \mathrm{M}$ distances are generally dependent upon the ionic radius of the incorporated secondary metals (see SI, Figure S113, right panel); at the short end, [Pd,Lu] and [Pd,Y] display rather short Pd•••M distances of ca. 3.4 $\AA$ and at the long end, [Pd,K] displays a distance of ca. $3.7 \AA$. On the other hand, the $\mathrm{Pd} \cdot \cdots \mathrm{M}$ distances for this family of complexes also show an appreciable linear relationship with the $p K_{a}$ values of the incorporated secondary metal ions (see SI, Figure S113, left panel). An opportunity for future work thus lies in expanding the libraries of heterobimetallic complexes in order to provide a solid understanding of the features that engender the structural properties of macrocyclic, heterobimetallic complexes. The $\mathrm{Pd}-\mathrm{N}$ and $\mathrm{Pd}-\mathrm{O}$ distances do not change significantly across the series of heterobimetallic complexes, while the $\mathrm{O} 1 \cdots \mathrm{O} 2$ distance can be seen to contract significantly upon incorporation of the Lewis acidic metal ions. We conclude that the macrocyclic framework, particularly the crown ether site, is sufficiently flexible to allow the Lewis acidic metals to comfortably bind with the electron-rich phenoxide donors in all cases. The values of the $01 \cdots 02$ separation are actually quite small, and are at or below the estimated Van der Waals distance for oxygen of $2.8 \AA,{ }^{[28]}$ and thus the Lewis acidic metals appear to interact strongly with the phenoxides, pulling them together and contracting the $\left[\mathrm{Pd}^{\prime \prime}\left(\mu_{2}-\mathrm{O}_{\mathrm{Ar}}\right)_{2} \mathrm{M}^{\mathrm{n}+}\right]$ diamond cores across the series. However, as noted above, strong covalent bonding holds the $\mathrm{Pd}(\mathrm{II})$ site together in all the complexes, as evidenced by the narrow range of $T_{4}$ values (vide supra) and the $\omega_{\text {salmen }}$ values showing little loss of planarity of the ligands to Pd(II) across the series (see Table 1). 


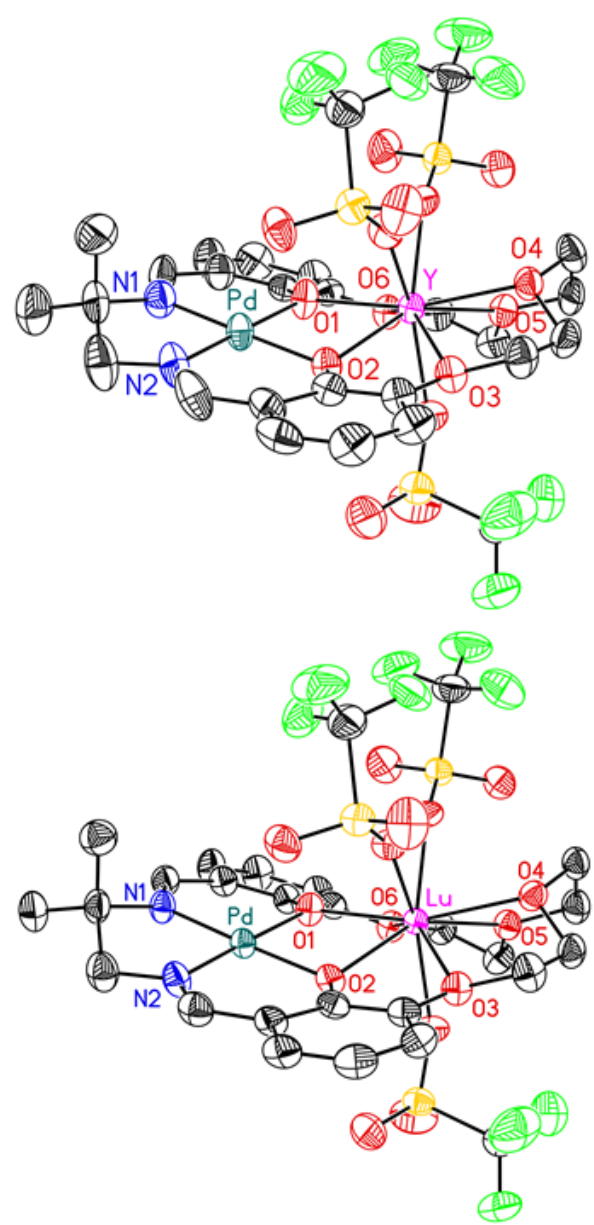

Figure 3. Solid-state structure (XRD) of [Pd,Y] and [Pd,Lu]. Hydrogen atoms and two co-crystallized MeCN solvent molecules in both [Pd,Y] and [Pd,Lu] structures are omitted for clarity. Displacement ellipsoids shown at the $50 \%$ probability level.

On the other hand, the $\omega_{\text {crown }}$ parameter varies widely across the series of heterobimetallic complexes (see Table 1). The crown is particularly distorted for the adducts incorporating trivalent Lewis acids. In prior work, we have ascribed this phenomenon to the preference of these ions for high coordination numbers. However, an additional feature that is observable in this data set, is that the $\omega_{\text {crown }}$ values are also quite large for the small trivalent ions, and thus the small size (and high Lewis acidity) of these ions likely drive the loss of planarity. In particular, the nestling of the Lewis acidic metals into the diamond core structure with bridging phenoxides can be visualized to result in a folding distortion of the crown-like site as the distal ether donors are pulled "up" and towards the diamond core in order to remain coordinated to the trivalent ion. The inner-sphere coordination of triflate also affects the planarity of the macrocycle, as can be seen in the structure of [Pd,Sr]; the two counterposed triflate ions seem to engender planarity in the macrocycle as evidenced by the small $\omega_{\text {crown }}$ value that is even more modest than the parent monometallic complex in which no metal ion is present in the crown to drive distortion.

With these results in hand, we next moved to interrogate the electronic properties of the heterobimetallic complexes with UVvisible spectroscopy. The spectrum of [Pd] (see SI, Figure S50) shows a result similar to previously studied non-macrocyclic $\mathrm{Pd}$ (II) salen-type complexes. Two absorption bands in the UV region $\left(\lambda_{\max }=250 \mathrm{~nm}, \varepsilon=36,600 \mathrm{M}^{-1} \mathrm{~cm}^{-1}\right.$ and $\lambda_{\max }=288 \mathrm{~nm}$, $\varepsilon=16,400 \mathrm{M}^{-1} \mathrm{~cm}^{-1}$ ) can be attributed to intraligand transitions of the conjugated framework. The additional and lowest energy

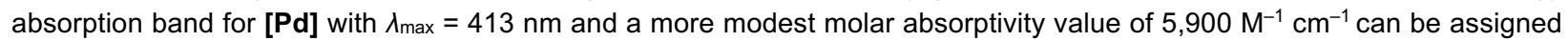
as having charge transfer character based on its position and intensity, and in agreement with a prior assignment. ${ }^{[29]}$ Further assigning this band as having metal-to-ligand charge transfer character is consistent with our prior work on [Zn,M] and [Ni,M] complexes supported by similar ligands. As in these prior cases for first-row transition metal complexes, incorporation of redoxinactive cations shifts the energy of the charge transfer band to higher values (see Figure 4), while the higher energy intraligand bands remain essentially invariant across the series of heterobimetallic complexes (see SI, Figures S58). Plotting the estimated $\lambda_{\max }$ values (in $\mathrm{eV}$ ) for the charge transfer bands as a function of the $\mathrm{p} K_{\mathrm{a}}$ values of the incorporated secondary metal 
ions returns a linear trend with a slope of $-45 \pm 3 \mathrm{meV} / \mathrm{pK}$ (see Figure 5). This tight relationship of $\lambda_{\max }$ with $\mathrm{p} K_{\mathrm{a}}$ contrasts with the very poor relationship of $\lambda_{\max }$ with the ionic radius of the incorporated secondary metal ions (see SI, Figure S59). In light of this observation, we tentatively conclude that charge density effects, quantifiable through Lewis acidity $\left(p K_{a}\right)$, are a better descriptor for electronic considerations in these palladium complexes, a conclusion bolstered by the electrochemical data as well (vide infra).

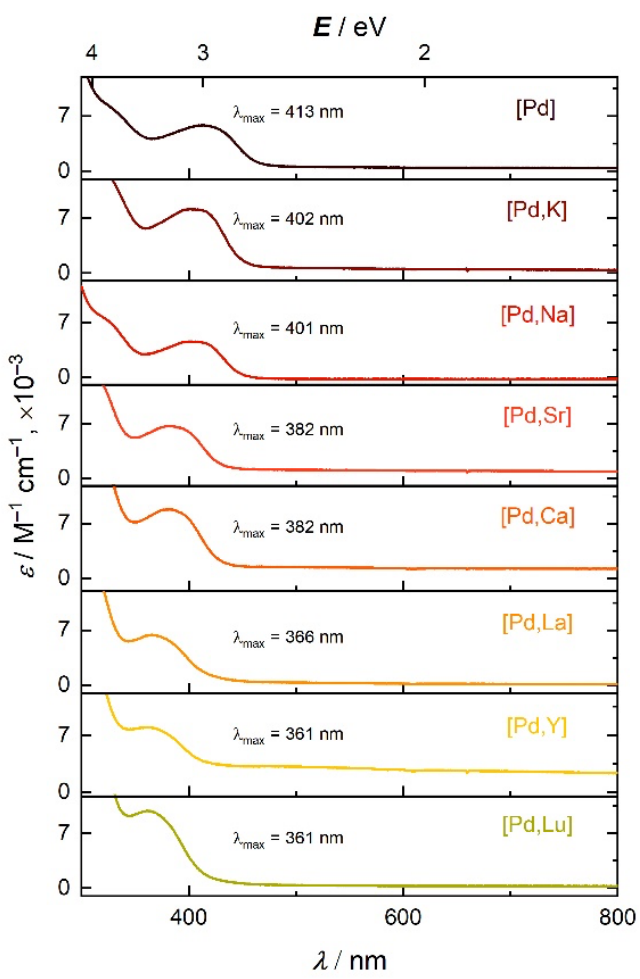

Figure 4. Stacked electronic absorption spectra of the $[\mathrm{Pd}]$ and $[\mathrm{Pd}, \mathrm{M}]$ complexes.

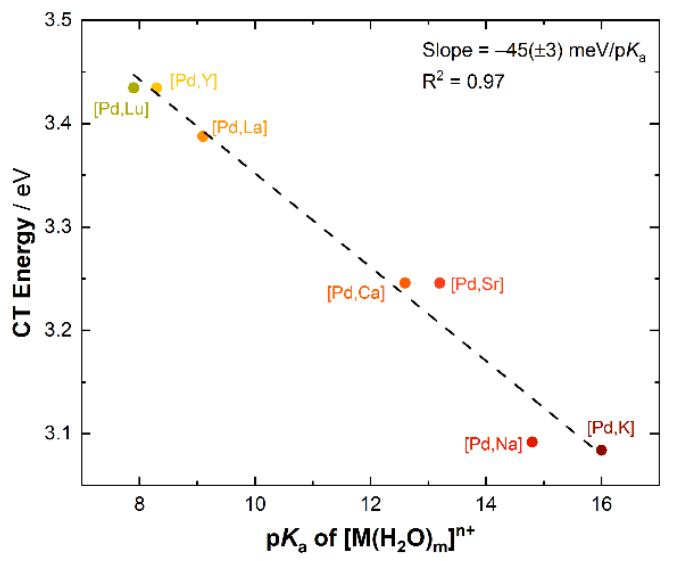

Figure 5. Dependence of the lowest-energy absorption band (CT energy) of the $[\mathrm{Pd}, \mathrm{M}]$ complexes on the Lewis acidity ( $\mathrm{p} K_{\mathrm{a}}$ ) of the corresponding $\mathrm{M}$ aqua complexes.

The dependence of the $\lambda_{\max }$ values (i.e., charge transfer energies) on $\mathrm{p} K_{\mathrm{a}}$ measured here for the $[\mathrm{Pd}, \mathrm{M}] \mathrm{series}(-45 \pm 3$ $\left.\mathrm{meV} / \mathrm{p} K_{\mathrm{a}}\right)$ is indistinguishable within error $( \pm 1 \sigma)$ from the dependence of a similar band measured for our heterobimetallic $[\mathrm{Ni}, \mathrm{M}]$ complexes in prior work $(-46 \pm 5)$. On the other hand, the absolute values of the charge transfer energies in the complexes studied here (ca. $3.1-3.5 \mathrm{eV}$ ) are greater than the values for our prior [Ni,M] complexes (ca. 2.6-2.9 eV). This difference is readily ascribable to the less conjugated $L^{\text {salmen }}$ framework used here, as well as the anticipated wider range in 
$d$-orbital energies for $\mathrm{Pd}(\mathrm{II})$ in comparison with $\mathrm{Ni}(\mathrm{II})$. The shift of the charge transfer energy to higher values in the complexes studied here can be ascribed to stabilization of the occupied orbitals on the metal, a working model that applies to all of the heterobimetallic complexes that we have studied. In this working model, stabilization of the metal-centered HOMO is achieved by interaction of the Lewis acidic secondary metals with the bridging phenoxide donors that are bound to the Pd(II) center. The effect of the redox-inactive cations on the ligand-centered LUMO orbitals, however, must be more modest in comparison to the shifts induced at the $\mathrm{Pd}(\mathrm{II})$ center, with the net result of the widening of the HOMO-LUMO gap that drives the shifts in the charge transfer band energies. As the anticipated change in donor power of the phenoxide ligands could be modeled as a shift in oxygen-centered charge density, it is not surprising that the preferred descriptor for the changes in the UV-visible spectra is the Lewis acidity (quantified through $\mathrm{p} K_{\mathrm{a}}$ ) of the incorporated metal ions.

Having observed the dependence of the charge transfer energies on the Lewis acidity values of the incorporated secondary metal ions, we were curious to investigate the possibility of accessible reductive electrochemistry for these complexes. As electrochemical data have not been previously available for heterobimetallic complexes of Pd(II) across a full range of mono-, di-, and tri-valent metals, we anticipated that understanding the roles of these ions in governing the redox chemistry of the complexes could reveal new insights into the tuning of heavier metal complexes by Lewis acidic cations. Yang's recent work on pincer-type $\mathrm{Pd}(\mathrm{II})$ complexes $^{[22]}$ nicely demonstrates the utility of such heterobimetallic species; our study builds further by probing across a wider range of Lewis acidic secondary metal ions including the challenging trivalents.

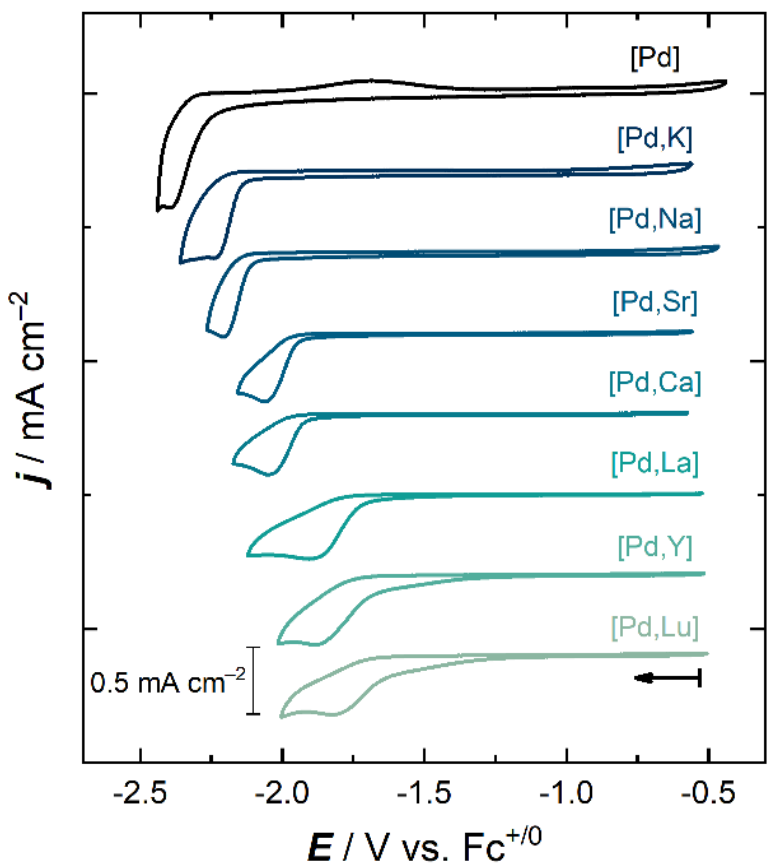

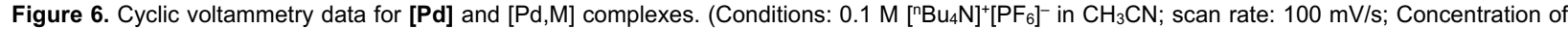
the complexes $=2 \mathrm{mM}$ )

Cyclic voltammograms collected for [Pd] revealed a single, irreversible cathodic wave at a quite negative reduction potential $\left(E_{p, c}=-2.40 \mathrm{~V}\right.$ vs. the ferrocenium/ferrocene couple, denoted hereafter as $\mathrm{Fc}^{+/ 0}$; see SI, Figure S62). No return anodic wave was evident in data at scan rates up to $300 \mathrm{mV} / \mathrm{s}$ (see SI, Figure S63), indicating the involvement of a fast follow-up chemical reaction after reduction of [Pd]. Thus, we assign this reduction as an EC-type process, in which a chemical reaction follows the initial electrochemical reduction. However, scan rate-dependent studies confirm that the starting complex is freely diffusing at the electrode surface, consistent with the solubility of [Pd] in MeCN (see SI, Figure S63).

Following the electrochemical study of [Pd], we investigated the influence of the installed Lewis acids on the reduction chemistry of the heterobimetallic derivatives. All of the compounds exhibit irreversible reduction processes that are similar to the EC behavior encountered with [Pd]. The cathodic peak currents were linearly dependent upon scan rate for all the [Pd,M] 
complexes (see SI, Figures S65, S67, S69, S71, S73, S75, and S77), consistent with the well-defined, molecular nature of the complexes. The cathodic potential required for reduction of [Pd,Na] is $-2.21 \mathrm{~V} \mathrm{vs.} \mathrm{Fc}^{+/ 0}$ (see SI, Figure S66), supporting retention of the Lewis acid in the crown ether cavity so that it can shift of the reduction potential for this complex to the more positive value than that for reduction of [Pd]. This trend of reduction potentials shifted to more positive values for the bimetallic derivatives continues across the entire series of complexes; derivatives containing divalent metals are shifted more than those incorporating monovalent metals, and the derivatives incorporating trivalent metals are shifted further still. Inspection of the $E_{p, c}$ value for $[\mathbf{P d}, \mathrm{Lu}]$ reveals that the reduction potential of this complex $(-1.86 \mathrm{~V})$ is shifted by the greatest amount in comparison to that of the monometallic precursor [Pd] $(-2.40 \mathrm{~V})$. This corresponds to a sizeable shift of $540 \mathrm{mV}$ for $\mathrm{Lu}^{3+}$, which is the strongest Lewis acids in our series, on the basis of the $\mathrm{p} K_{\mathrm{a}}$ value scale measured in $\mathrm{H}_{2} \mathrm{O}$. ${ }^{\left[{ }^{30]}\right.}$ In light of these observations, we conclude that mono-, di-, and tri-valent redox-inactive metal ions are useful for tuning the reduction potentials of palladium complexes.

Having observed the irreversible features in cyclic voltammetry data for all the $[\mathrm{Pd}, \mathrm{M}]$ complexes, we wondered whether the observed cathodic waves correspond to ligand-centered or metal-centered reduction processes. ${ }^{[31]}$ Inspection of the literature reveals that the $\mathrm{Pd}(\mathrm{II})$ oxidation state tends to be quite stable in $\mathrm{L}_{2} \mathrm{X}_{2}$-type, square-planar ligand environments, and thus generation of lower oxidation states only occurs at much more negative potentials. Most reports regarding the electrochemical properties of palladium-salen complexes focus on oxidative processes, ${ }^{[32]}$ and virtually no studies of reductive processes are available in the literature. ${ }^{[33]} \mathrm{The} \mathrm{Pd}(\mathrm{I})$ oxidation state is not commonly accessible under standard aqueous conditions, a feature attributable to the high stability of both $\mathrm{Pd}(\mathrm{II})$ and $\mathrm{Pd}(0)$ and reflected in the rather positive oxidation potential estimated for $\operatorname{Pd}(0)$ itself. ${ }^{[34]}$ Brown and co-workers have discussed the preference for the $+\|$ oxidation state in situations involving phenoxide-based ligands, based upon a compelling thermodynamic argument regarding this preference that focuses on the destabilization of the relevant metal-centered orbitals by metal.•.ligand $\sigma$ bonding with palladium and platinum. ${ }^{\left[{ }^{[1]}\right.}$ In the context of our work, we anticipated that pursuing more evidence regarding the nature of the reduction processes for the [Pd,M] complexes could be quite useful, as our heterobimetallic complexes display an apparently tunable manifold of reduction chemistry; the similarity of the reduction processes measured for each compound suggested to us that quantification of the properties of these reductions as a function of Lewis acidity might provide new insights into the often difficult problem of distinguishing between metal- and ligand-centered reduction in heavier metal complexes. ${ }^{[35,36]}$

To investigate the nature of the reduction chemistry, we started by performing electrochemical experiments on the precursor complex lacking palladium denoted $\left[\mathrm{H}_{2}, \mathrm{Ba}\right]$ (vide supra). This complex undergoes an obvious and irreversible reduction at $E_{p, c}=-1.97 \mathrm{~V}$ vs. $\mathrm{Fc}^{+/ 0}$ (see SI, Figure S60). The only metal ion present in $\left[\mathrm{H}_{2}, \mathrm{Ba}\right]$ is $\mathrm{Ba}(\mathrm{II})$, and therefore the only possible sites for reduction are $\mathrm{L}^{\text {salmen }}$ and $\mathrm{Ba}$ (II) itself. Much like $\mathrm{Zn}(\mathrm{II}), \mathrm{Ba}(\mathrm{II})$ is considered a redox-inactive metal under typical conditions, with a standard reduction potential under basic conditions for $\mathrm{Ba}^{\prime \prime} / \mathrm{Ba}^{0}$ interconversion of $-2.92 \mathrm{~V}$ vs. the normal hydrogen electrode (NHE). ${ }^{[34]}$ This value (in base) is strikingly negative when compared to the corresponding $Z n^{\prime \prime} / Z n^{0}$ reduction potential under basic conditions of only ca. $-1.27 \mathrm{~V}$ vs. NHE (depending on coordination number). The significantly more negative potential for reduction of $\mathrm{Ba}(\mathrm{II})$ supports the notion that $\mathrm{Ba}(\mathrm{II})$ is redox-inactive under our conditions in [ $\mathrm{H}_{2}, \mathrm{Ba}$ ], and thus, we assign the reduction of the compound at $E_{\mathrm{p}, \mathrm{c}}=-1.97 \mathrm{~V}$ as a $\mathrm{L}^{\text {salmen }}$-centered reduction. The more positive reduction potential of $\left[\mathrm{H}_{2}, \mathrm{Ba}\right](-1.97 \mathrm{~V})$ as compared to [Pd] $(-2.40 \mathrm{~V})$ could be attributable to the presence of $\mathrm{Ba}(\mathrm{II})$ in the macrocyclic structure, in addition to the presence of two phenolic protons (Brønsted acids) in the ligand structure.

Low temperature electrochemistry experiments were also carried out, in order to attempt direct observation of reduced forms of the complexes in this study. We anticipated that a chemical reaction associated with the EC processes in the [Pd,M] complexes would be retarded at low temperatures. Therefore, we recorded cyclic voltammograms of monometallic [Pd] at approx. $-78^{\circ} \mathrm{C}$ by using a dry ice/acetone bath to cool the electrochemical cell and working solution, substituting propionitrile

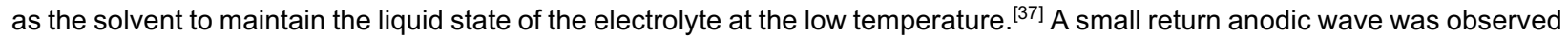
in the CV of [Pd] at low temperature (see SI, Figure S78), suggesting limited chemical reversibility under these conditions. However, no return waves were observed in the data for [Pd,Na] and [Pd,Sr] complexes at low temperature (see SI, Figures S79 and S80). This indicates that the follow-up chemical reactivity is rapid, even at low temperature, an observation consistent with ligand-centered radical reactions. Older work from Vianello and newer work from Mazzanti (albeit not concerning Pd complexes) support the possibility of such reactivity, attributable to localization of reactive electron density on the imine carbons following reduction that promotes intermolecular $\mathrm{C}-\mathrm{C}$ coupling reactions. ${ }^{[38]}$ 
In prior work, we showed that zinc complexes of a related heteroditopic ligand framework could be synthesized, ${ }^{[15]}$ and thus, we attempted here to synthesize a zinc-containing analogue of [Pd] (see Scheme 2). $\mathrm{Zn}(\mathrm{OAc})_{2} \cdot 2 \mathrm{H}_{2} \mathrm{O}$ was used with a synthetic technique similar to that used for preparation of [Pd] (see Scheme 2 and Experimental Section). Multiple attempts revealed that the product of this synthesis, however, was not the anticipated monometallic zinc complex. Single crystals of the product, denoted by $\left[\mathbf{Z} \mathbf{n}_{\mathbf{2}}\right]$, suitable for XRD analysis were obtained, revealing that [ $\mathbf{Z} \mathbf{n}_{\mathbf{2}}$ ] is a structurally complex homobimetallic species featuring two zinc centers; one zinc occupies the Schiff-base cavity, and a second zinc sits "above" the crown ether site.

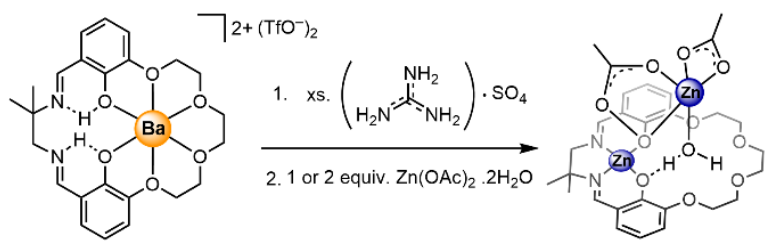

Scheme 2. Synthesis strategy for preparation of $\left[\mathrm{Zn}_{2}\right]$ complex.

The structure of $\left[\mathbf{Z n}_{2}\right]$ is highly unusual (see Figure 7 ), and is supported by bridging acetate ligands that are incorporated into the isolated material. The zinc centers are connected through a bridging acetate group, and a second, terminal acetate group is bound to the zinc located above the crown ether site, binding in a $\kappa^{2}$ mode. Both zinc atoms in [ $\left.\mathbf{Z n}_{2}\right]$ display coordination numbers of five, similar to the $\mathrm{Zn}^{2+}$ centers found in our prior zinc complexes. ${ }^{[15]}\left[\mathrm{Zn}_{2}\right]$ also incorporates a single zinc-bound water molecule that engages in intramolecular hydrogen bonding with a nearby oxygen of a free ether moiety. This unique structure allows both the $\mathrm{Zn}$ atoms to reach the coordination number of five and appears to stabilize the overall structure. Elemental analysis confirming the composition of $\left[\mathbf{Z n}_{2}\right]$ was obtained; the experimental data showed the presence of an additional 0.5 equiv. of $\mathrm{H}_{2} \mathrm{O}$ per $\left[\mathbf{Z n}_{2}\right]$, however, consistent with our observation that the isolated compound is hygroscopic in nature.

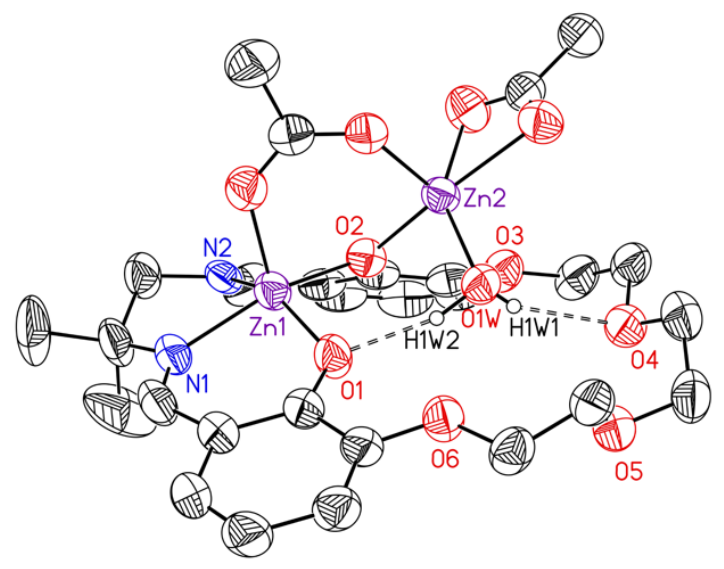

Figure 7. Solid-state structure (XRD) of $\left[\mathrm{Zn}_{2}\right]$. Hydrogen atoms are omitted for clarity except $\mathrm{H} 1 \mathrm{~W} 1$ and $\mathrm{H} 1 \mathrm{~W} 2$. Displacement ellipsoids shown at the $50 \%$ probability level.

Based on ${ }^{1} \mathrm{H}$ NMR data, the structure of $\left[\mathbf{Z n}_{2}\right]$ is fluxional in solution. Only a single acetate resonance (integrating to $6 \mathrm{H}$ ) was observed in $\mathrm{CD}_{3} \mathrm{CN}$ (see SI, Figure S44), indicating that the acetate ligands in [ $\mathbf{Z} \mathbf{n}_{2}$ ] are rapidly exchanging between environments in solution and thus are magnetically equivalent. On the other hand, the resonances corresponding to the protons of the $L^{\text {salmen }}$ framework are unique in $\left[\mathbf{Z n}_{2}\right]$, and thus we anticipate that the zinc centers in the complex remain coordinated to $\mathrm{L}^{\text {salmen }}$ in solution. This is consistent with the highly Lewis acidic nature of $\mathrm{Zn}(\mathrm{II})$, and its tendency to adopt a C.N. of five.

Returning to the question of ligand-centered redox chemistry for $L^{\text {salmen }}, C V$ data for $\left[\mathbf{Z} \mathbf{n}_{\mathbf{2}}\right]$ reveal an irreversible reduction at $E_{\mathrm{p}, \mathrm{c}}=-2.44 \mathrm{~V}$ vs. $\mathrm{Fc}^{+/ 0}$ (see SI, Figure S81). This value is similar to the $E_{\mathrm{p}, \mathrm{c}}$ value measured for $[\mathrm{Pd}]$ at $-2.40 \mathrm{~V}$ vs. $\mathrm{Fc}^{+/ 0}$, and 
thus observation of the reduction of $\left[\mathbf{Z n}_{\mathbf{2}}\right]$ provides further support for the notion that reduction of [Pd] is ligand-centered. We note here that our prior electrochemical studies of a salophen-derived homobimetallic zinc complex revealed a more positive reduction potential of $-1.69 \mathrm{~V}$ vs. $\mathrm{Fc}^{+/ 0}$ that was assigned as a salophen ligand-centered reduction. ${ }^{[15]}$ The more negative value of the reduction potential for $\left[Z_{2} n_{2}\right.$ is consistent with the less conjugated nature of the $L^{\text {salmen }}$ framework used to support the complexes in this study. On the basis of all these chemical and electrochemical findings, we thus assign all the reduction processes measured here for the $[\mathrm{Pd}, \mathrm{M}]$ complexes as ligand-centered in nature.

Tabulation and comparison of the peak reduction potentials of the cathodic features $\left(E_{p, c}\right.$ values $)$ for all of the heterobimetallic $\mathrm{Pd}$ complexes can be used to quantify the influence of the redox-inactive metals on the redox properties of the complexes. $\mathrm{A}$ linear relationship is revealed by plotting $E_{p, c}$ (derived from the data in Figure 6) as a function of the p $K_{a}$ values of the aqua complexes of the corresponding secondary metal ions. The linear relationship displays a slope of $-48( \pm 3) \mathrm{mV} / \mathrm{p} K_{a}(\mathrm{see} F i g u r e$ 8). Thus, when Lewis acidic metals are coordinated to [Pd], there is a uniform trend of modulated ligand-centered reduction potential. In our prior work with zinc complexes, ${ }^{[15]}$ the linear relationship was strikingly similar, giving a slope of $-41( \pm 3) \mathrm{mV} / \mathrm{p} K_{\mathrm{a}}$. The nearly indistinguishable quantitative relationships between $E_{\mathrm{p}, \mathrm{c}}$ and $\mathrm{p} K_{\mathrm{a}}$ in these systems suggest similar influences of the secondary metal ions in both cases.

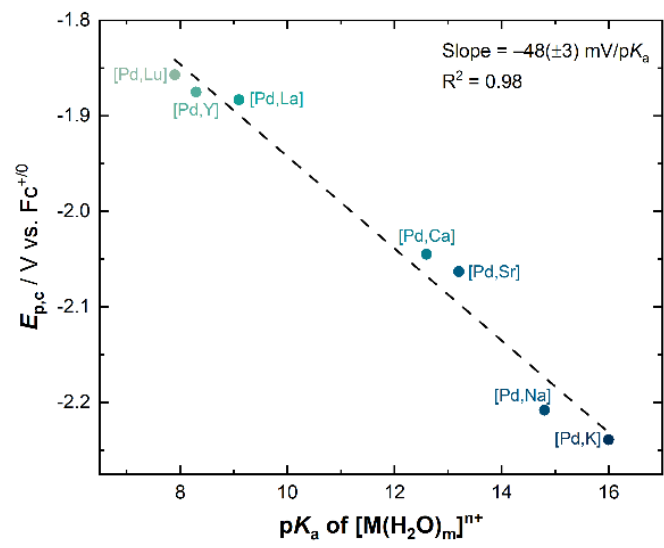

Figure 8. Plot of $E_{\mathrm{p}, \mathrm{c}}\left([\mathrm{Pd}]^{\prime \prime \prime I}\right)$ vs. $\mathrm{p} K_{\mathrm{a}}$ of $\left[\mathrm{M}\left(\mathrm{H}_{2} \mathrm{O}\right)_{\mathrm{m}}\right]^{\mathrm{n}+}$

In the CV data shown in Figure 6, another trend in the appearance of the reductive waves can be observed. As the Lewis acidity of the secondary metal ions increases, the shape of the reductive waves broadens. This is particularly apparent when comparing the data for [Pd,Na], a complex containing the quite weakly Lewis acidic $\mathrm{Na}^{+}$ion, and [Pd, Lu], a complex containing the strongly Lewis acidic and trivalent $\mathrm{Lu}^{3+}$ ion. Broadened reductive waves are generally consistent with slower heterogeneous electron transfer rates $\left(k^{\circ}\right)$, a phenomenon attributable to decrease in the exchange current density for processes that involve significant barriers to electron transfer ${ }^{[39]}$ In the cases of the compounds described here, however, there is no paired re-oxidation wave, and thus quantification of $k^{\circ}$ by the well-known method of Nicholson based on $\Delta E_{\mathrm{p}}$ values cannot be carried out. ${ }^{[40]}$

On the other hand, the reorganization energies $(\lambda)$ associated with the individual electron transfer processes measured here can be quantified. The reorganization energy is a key kinetic parameter associated with electron transfer kinetics, as described in the Marcus theory of electron transfer. ${ }^{[41]}$ Conventionally, $\lambda$ includes both an inner-sphere component related to the reorganization of the complex upon reduction and an outer-sphere component corresponding to solvation changes upon reduction. In general, smaller values of $\lambda$ are associated with faster electron transfer, while larger values are associated with slower electron transfer. The electrode itself is typically considered to undergo virtually no reorganization, and thus does not contribute to reorganization energy penalties in consideration of the kinetics of heterogeneous electron transfer events. Here, we anticipated that the $\lambda$ values associated with electron transfer to the $[\mathrm{Pd}, \mathrm{M}]$ complexes should influence the heterogeneous electron transfer kinetics associated with their reduction, and thus sought to estimate the $\lambda$ values for each of the complexes. 
Table 2. Electrochemical Characteristics of the $[\mathrm{Pd}, \mathrm{M}]$ complexes.

\begin{tabular}{|c|c|c|c|c|}
\hline $\begin{array}{l}\text { Name of the } \\
\text { complex }\end{array}$ & $\begin{array}{c}p K_{a} \text { of } \\
{\left[\mathrm{M}\left(\mathrm{H}_{2} \mathrm{O}\right)_{\mathrm{m}}\right]^{\mathrm{n}}}\end{array}$ & $E_{\mathrm{p}, \mathrm{c}}(\mathrm{V})^{[\mathrm{a}]}$ & $E_{\mathrm{p} / 2}(\mathrm{~V})^{[\mathrm{b}]}$ & $\lambda(\mathrm{eV})^{[\mathrm{b}]}$ \\
\hline [Pd] & - & -2.40 & -2.33 & 0.26 \\
\hline$[\mathrm{Pd}, \mathrm{K}]$ & 16 & -2.24 & -2.19 & 0.16 \\
\hline$[\mathrm{Pd}, \mathrm{Na}]$ & 14.8 & -2.21 & -2.15 & 0.17 \\
\hline$[\mathrm{Pd}, \mathrm{Sr}]$ & 13.2 & -2.06 & -1.99 & 0.26 \\
\hline$[\mathrm{Pd}, \mathrm{Ca}]$ & 12.6 & -2.05 & -1.96 & 0.27 \\
\hline$[\mathrm{Pd}, \mathrm{La}]$ & 9.1 & -1.88 & -1.78 & 0.81 \\
\hline$[\mathrm{Pd}, \mathrm{Y}]$ & 8.3 & -1.87 & -1.76 & 0.91 \\
\hline$[\mathrm{Pd}, \mathrm{Lu}]$ & 7.9 & -1.86 & -1.69 & 1.25 \\
\hline
\end{tabular}

[a] Measured at $100 \mathrm{mV} / \mathrm{s}$. [b] Average of measurements at four different scan rates $(50 \mathrm{mV} / \mathrm{s}, 100 \mathrm{mV} / \mathrm{s}, 150 \mathrm{mV} / \mathrm{s}$, and $200 \mathrm{mV} / \mathrm{s})$.

We calculated the $\lambda$ values here using the powerful method of Savéant and Costentin. ${ }^{[42]}$ In their method, the broadness of a voltammetric wave is assessed by comparison of the $E_{\mathrm{p}, \mathrm{c}}$ and $E_{\mathrm{p} / 2}$ values, where $E_{\mathrm{p} / 2}$ is the voltammetric potential at which the half-maximum current is flowing (see SI, p. S49 for details). With this method, we determined the $\lambda$ value for the [Pd] complex to be a modest $0.25 \mathrm{eV}$, consistent with the relatively fast electron transfer behavior exhibited in the $\mathrm{CV}$ data for this complex. Upon incorporation of more Lewis acidic ions, the reorganization energies for the [Pd,M] complexes increase monotonically up to ca. $1.25 \mathrm{eV}$ (see Table 2). This indicates that the heterobimetallic complex with the most Lewis acidic ion in the series, $[\mathrm{Pd}, \mathrm{Lu}]$, has the highest reorganization energy and thus the slowest heterogeneous electron transfer kinetics among all the complexes studied here. Plotting the $\lambda$ values on a log scale reveals a linear relationship with $p K_{a}$, providing an insight into the Lewis acid-driven modulation of electron transfer kinetics. This represents a striking counterpoint to the $E_{\mathrm{p}, \mathrm{c}}$ vs. pKa relationship shown in Figure 8, which was intended here as a proxy for the influence of Lewis acidity on the thermodynamic reduction potential, in that this trend demonstrates that the complexes undergo greater reorganization upon reduction when they incorporate stronger Lewis acidic metals, like the trivalent ions. This behavior strongly resembles that which we have previously measured in heterobimetallic uranyl complexes. ${ }^{[13]}$

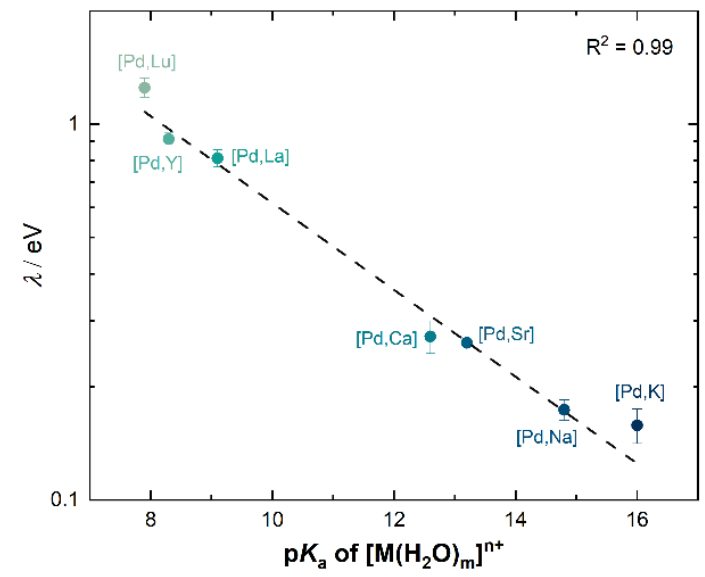

Figure 9. Plot of $\lambda$ for the $[\mathrm{Pd}, \mathrm{M}]$ complexes vs. $\mathrm{pK}$ of $\left[\mathrm{M}\left(\mathrm{H}_{2} \mathrm{O}\right)_{\mathrm{m}}\right]^{\mathrm{n}}$. $\lambda$ values were computed with data measured at four different voltammetric scan rates $(50 \mathrm{mV} / \mathrm{s}, 100 \mathrm{mV} / \mathrm{s}, 150 \mathrm{mV} / \mathrm{s}$, and $200 \mathrm{mV} / \mathrm{s})$. 


\section{Discussion}

In our prior studies of heterobimetallic nickel, zinc, and uranyl complexes supported by similar ligand frameworks, the effects of Lewis acids on the electronic structure of the complexes were studied by tabulating the charge transfer (CT) energies from electronic absorption spectroscopy as a function of $\mathrm{p} K_{\mathrm{a}}{ }^{[13,14,15]}$ The shift in the CT energy for the [Pd,M] series was calculated to be $-45( \pm 3) \mathrm{meV} / \mathrm{p} K_{\mathrm{a}}$, which is comparable to those measured for $[\mathrm{Ni}, \mathrm{M}]^{[14]}$ and $[\mathrm{Zn}, \mathrm{M}]^{[15]}\left(-46( \pm 5) \mathrm{meV} / \mathrm{p} K_{\mathrm{a}}\right.$ and $-43( \pm 9)$ $\mathrm{meV} / \mathrm{p} K_{\mathrm{a}}$, respectively). This similarity suggests that the electronic tuning of complexes by the Lewis acidic metals operates via a similar mode in all three cases, despite the prediction of stronger metal•••ligand $\sigma$ bonding for palladium in place of nickel. However, as the effect of the Lewis acids on the $L^{\text {salmen }}$-centered orbitals should be stronger than the effect on the Pd-centered orbitals, this similarity is understandable. On the other hand, these $\mathrm{meV} / \mathrm{p} K_{\mathrm{a}}$ values calculated for heterobimetallic complexes of transition metals are significantly larger as compared to the $\left[\mathrm{UO}_{2}, \mathrm{M}\right]$ series that contains actinide metal $\mathrm{U}$, which showed a shift of $-22( \pm 1) \mathrm{meV} / \mathrm{pK} \mathrm{a}^{\left[{ }^{[13]}\right.}$ This significant difference in the $\mathrm{meV} / \mathrm{p} K_{\mathrm{a}}$ value could be attributed to greater involvement of the uranium-centered orbitals in the measured charge-transfer bands, or a change in the influence of the Lewis acidic metals on the ligand orbitals (specifically, phenoxide-based orbitals).

In this work, we were excited to understand the modulation of redox chemistry by Lewis acidic metals in heterobimetallic complexes of $\mathrm{Pd}$, in order to compare the sensitivity of the modulation for a later transition metal with results already available from prior work in our group on heterobimetallic complexes of $\mathrm{Ni}(\mathrm{II}), \mathrm{Zn}(\mathrm{II})$, and $\mathrm{UO}_{2}{ }^{2+}$. Plotting cathodic peak reduction potentials $\left(E_{\mathrm{p}, \mathrm{c}}\right.$ values) vs. the $\mathrm{p} K_{\mathrm{a}}$ values associated with the aqua complexes of the incorporated Lewis acidic metals ${ }^{[24]}$ is a convenient method to accomplish this goal, and in the case of the new [Pd,M] complexes studied here, the sensitivity of the tuning corresponds to a relationship of $-48( \pm 3) \mathrm{meV} / \mathrm{p} K_{\mathrm{a}}$. This value is fairly similar to that previously measured for our $[\mathrm{Zn}, \mathrm{M}]$ complexes of $-41( \pm 3) \mathrm{meV} / \mathrm{p} K_{\mathrm{a}}$ but much lower than the trend seen for the $[\mathrm{Ni}, \mathrm{M}]$ series of $-70( \pm 12) \mathrm{meV} / \mathrm{p} K_{\mathrm{a}}$ and that for the $\left[\mathrm{UO}_{2}, \mathrm{M}\right]$ series of $-61( \pm 9) \mathrm{meV} / \mathrm{pK}$. This implies that the nature of the redox processes occurring with $[\mathrm{Pd}, \mathrm{M}]$ and $[\mathrm{Zn}, \mathrm{M}]$ complexes is distinctive. In the case of $[\mathrm{Ni}, \mathrm{M}]$ and $\left[\mathrm{UO}_{2}, \mathrm{M}\right]$ complexes, metal-centered orbitals take up the transferred electrons, which was confirmed by spectroelectrochemical results particularly in the case of the uranyl complexes. In the case of our $\mathrm{Pd}$ and $\mathrm{Zn}$ complexes, we anticipate that ligand-centered orbitals take up the transferred electrons; multiple lines of electrochemical evidence support this assignment (vide supra). The conjugated framework of the ligand that contains the important orbital(s) which take up the transferred electron(s) is separated from the secondary, Lewis acidic cations by a greater spatial distance than the redox-active $\mathrm{Ni}$ and $\mathrm{U}$ centers in the other complexes. As a result, the impact of the redox-inactive cations on the ligand-centered reductions can be understood as being more modest than in the Ni and $\mathrm{U}$ complexes. Taken all together, the quantified trends in these data can be proposed as a new probe (or descriptor) for distinguishing metal- and ligand-centered reduction processes in heterobimetallic complexes.

In addition to the uniform trend in $E_{\mathrm{p}, \mathrm{c}}$ observed for the heterobimetallic complexes, the more Lewis acidic metals engender slower electron transfer rates to the $[\mathrm{Pd}, \mathrm{M}]$ complexes. This was investigated here by determination and comparison of the reorganization energies ( $\lambda$ values) associated with the reduction processes. This kinetic behavior for the [Pd,M] series is notably similar to the behavior that we previously measured for $\left[\mathrm{UO}_{2}, \mathrm{M}\right]$ complexes, despite the situation that the uranium centers undergo reduction from the $+\mathrm{VI}$ oxidation state to $+\mathrm{V}$ in the complexes. This consistency between the reorganization energy trends makes sense, however, if the presence of a strongly Lewis acidic cation induces significant follow-up chemical reactivity to the electron transfer events in question. We anticipate that the chemical reactivity that results from the first electron transfer event could be quite diverse, particularly depending on the identity of the redox-inactive metal. The uranyl ion, with its terminal oxo ligands, is known to become activated for $\mathrm{U}-\mathrm{O}$ cleavage upon reduction, ${ }^{[16]}$ giving a possible assignment for the follow-up chemical reactivity in the $\left[\mathrm{UO}_{2}, \mathrm{M}\right]$ series. Increased reorganization energy for the [Pd,M] complexes could be attributed to increasingly significant changes which occur upon reduction of the adducts containing more Lewis acidic ions. This concept is supported by the overall lower reorganization energies measured for our more rigid and highly conjugated zinc complexes from prior work, ${ }^{[15]}$ although all the values in these studies are reasonable in comparison with prior kinetic studies of homogeneous electron transfers to smaller, fully conjugated organic molecules. ${ }^{[4]}$ Consequently, we conclude that Lewis acidic redox-inactive metals can not only influence the thermodynamics of the reduction of redox-active metal complexes (estimated here with $E_{p, c}$ values) but also strongly influence the kinetics of the heterogeneous electron transfer processes (estimated here with $\lambda$ values). This interplay of kinetic and thermodynamic behavior and influence could be useful for developing new redox chemistries that involve multiple metals. The work described here represents a platform on which we could investigate redox processes associated with palladium complexes, in an area of the periodic table where Lewis acid effects have been little explored to date. However, on the basis of all the findings, modulation of redox chemistry with redoxinactive cations deserves significant further attention, as this approach continues to appear broadly applicable. 


\section{Conclusion}

We have prepared a series of heterobimetallic complexes of palladium(II) supported by a heteroditopic ligand platform, and we have demonstrated that the electronic and reductive electrochemical properties of the complexes can be rationally tuned by inclusion of mono-, di-, and tri-valent redox-inactive Lewis acidic cations. This report represents one of the few instances of preparation of well-defined heterobimetallic complexes containing palladium, and a comprehensive study of the role of the redox-inactive metals in tuning the heterogeneous electron transfer behavior of such complexes. These results highlight the potential of incorporation of secondary metal ions for developing new redox chemistries that involve heavier metals. As controlling the redox properties of complexes of the heavier metals is an area deserving of attention, preparation of heterobimetallic species represents an appealing strategy in this realm.

\section{Experimental Section}

\section{General Considerations}

All manipulations were carried out in dry $\mathrm{N}_{2}$-filled gloveboxes (Vacuum Atmospheres Co., Hawthorne, CA, USA) or under $\mathrm{N}_{2}$ atmosphere using standard Schlenk techniques unless otherwise noted. All solvents were of commercial grade and dried over activated alumina using a PPT Glass Contour (Nashua, NH) solvent purification system prior to use, and were stored over molecular sieves. All chemicals were obtained from major commercial suppliers and used as received or after extensive drying. 2,3-dihydroxybenzaldehyde was sublimed in vacuo before use. $\mathrm{CD}_{3} \mathrm{CN}$ for NMR studies was purchased from Cambridge Isotope Laboratories (Tewksbury, MA, USA) and dried over $3 \AA$ molecular sieves. ${ }^{1} \mathrm{H},{ }^{13} \mathrm{C}$, and ${ }^{19} \mathrm{~F}$ NMR spectra were collected on 400 or $500 \mathrm{MHz}$ Bruker spectrometers and referenced to the residual protio-solvent signal[44] in the case of ${ }^{1} \mathrm{H}$ and ${ }^{13} \mathrm{C}$. Heteronuclear NMR spectra were referenced to the appropriate external standard following the recommended scale based on ratios of absolute frequencies $(\equiv) \cdot{ }^{[45]}{ }^{19} \mathrm{~F}$ NMR spectra were referenced and reported relative to $\mathrm{CCl}_{3} \mathrm{~F}$. Chemical shifts $(\delta)$ are reported in units of ppm and coupling constants $(J)$ are reported in Hz. NMR spectra are given in the SI (Figures S2 to S48). Electronic absorption spectra were collected with an Ocean Optics Flame spectrometer equipped with DH-Mini light source, in a $1 \mathrm{~cm}$ path length quartz cuvette. Elemental analyses were performed by Midwest Microlab, Inc. (Indianapolis, IN, USA).

\section{Electrochemical Methods}

Electrochemical experiments were carried out in a $\mathrm{N}_{2}$-filled glovebox in dry, degassed $\mathrm{CH}_{3} \mathrm{CN}$. $0.10 \mathrm{M}$ tetra( $n$-butylammonium)

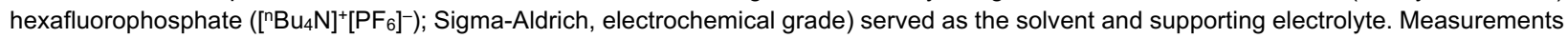
were carried out with a Gamry Reference 600+ Potentiostat/Galvanostat (Gamry Instruments, Warminster, PA, USA), using a standard threeelectrode configuration. The working electrode was the basal plane of highly oriented pyrolytic graphite (HOPG) (GraphiteStore.com, Buffalo Grove, III.; surface area: $0.09 \mathrm{~cm}^{2}$ ), the counter electrode was a platinum wire (Kurt J. Lesker, Jefferson Hills, PA; $99.99 \%, 0.5 \mathrm{~mm}$ diameter), and a silver wire immersed in electrolyte served as a pseudoreference electrode ( $\mathrm{CH}$ Instruments). The reference was separated from the working solution by a Vycor frit (Bioanalytical Systems, Inc., West Lafayette, IN, USA). Ferrocene (Sigma Aldrich, St. Louis, MO, USA; twicesublimed) was added to the electrolyte solution prior to the beginning of each experiment; the midpoint potential of the ferrocenium/ferrocene couple (denoted as $\mathrm{Fc}^{+/ 0}$ ) served as an external standard for comparison of the recorded potentials. Concentrations of analytes for cyclic voltammetry were typically $2 \mathrm{mM}$ unless otherwise noted. Experiments were conducted by first scanning cathodically, then anodically on the return sweep.

Low temperature electrochemistry experiments were performed in a custom-made cell equipped with three ports having Rodaviss joints along with $\mathrm{O}$ rings to ensure proper seal. The cell was packed and sealed inside glovebox by placing the complex solution of complex to be studied

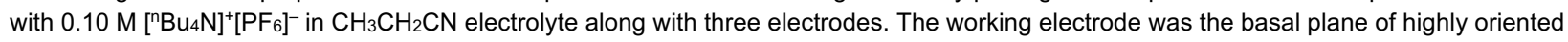
pyrolytic graphite (HOPG) (GraphiteStore.com, Buffalo Grove, III.; surface area: $0.09 \mathrm{~cm}^{2}$ ), and the counter and reference electrodes were both platinum wires (Kurt J. Lesker, Jefferson Hills, PA; $99.99 \%, 0.5 \mathrm{~mm}$ diameter). The low temperature (approx. $-78^{\circ} \mathrm{C}$ ) was achieved by immersing the cell in cooling bath of dry ice and acetone.

\section{Synthesis and characterization}

Synthesis of 3,3'-(3,6-Dioxaoctane-1,8-diyldioxy)bis(2-hydroxybenzaldehyde). A solution of 2,3-dihydroxybenzaldehyde (2.98 g, 21.6 $\mathrm{mmol}$ ) dissolved in $15 \mathrm{~mL}$ of dry THF was added dropwise to a Schlenk flask charged with a suspension of $\mathrm{NaH}(1.14 \mathrm{~g}, 47.5 \mathrm{mmol})$ in $10 \mathrm{~mL}$ of dry THF under $\mathrm{N}_{2}$ over a period of 2 hours with vigorous stirring. This addition was completed by maintaining the temperature of reaction 
mixture below $25^{\circ} \mathrm{C}$ using ice bath. The color of the mixture quickly changed to bright yellow due to the formation of disodium salt of $2,3-$ dihydroxybenzaldehyde. After the complete addition ice bath was removed and mixture was stirred for 1.5 hours at room temperature. A solution of triethylene glycol ditosylate $(4.95 \mathrm{~g}, 10.8 \mathrm{mmol})$ in $30 \mathrm{~mL}$ of dry THF was added to the Schlenk all at once using a syringe under positive flow of $\mathrm{N}_{2}$. The resulting mixture was then stirred for 60 hours at $40^{\circ} \mathrm{C}$ under static $\mathrm{N}_{2}$ atmosphere. Subsequent addition of $100 \mathrm{~mL}$ of water formed dark brown solution which was extracted with $\mathrm{CHCl}_{3}$ twice. The aqueous layer was acidified using $6 \mathrm{M} \mathrm{HCl}$ to $\mathrm{pH}$ and then extracted thrice with $\mathrm{CHCl}_{3}$. All three organic layers were combined and washed with $1 \mathrm{M} \mathrm{HCl}$ and dried over anhydrous $\mathrm{MgSO}_{4}$. The crude product was obtained by removal of solvent which was then washed with cold diethyl ether to afford the pale-yellow solid product. Yield: $73 \%$ $\left(2.02 \mathrm{~g}\right.$ ). Spectroscopic characterization by ${ }^{1} \mathrm{H}$ NMR (see SI, Figure S2) was done to confirm the expected structure and it was in agreement with a prior literature report. ${ }^{[7]}$

Synthesis of $\left[\mathrm{H}_{2} \mathrm{Ba}\right]$. A three-necked flask charged with the solution of $\mathrm{Ba}(\mathrm{OTf})_{2}(1.52 \mathrm{~g}, 3.49 \mathrm{mmol})$ dissolved in $350 \mathrm{~mL}$ of $\mathrm{CH}_{3} \mathrm{OH}(0.01 \mathrm{M})$ was allowed to reflux and then a solution of 3,3'-(3,6-Dioxaoctane-1,8-diyldioxy)bis(2-hydroxybenzaldehyde) (1.36 g, $3.49 \mathrm{mmol}$ ) in $35 \mathrm{~mL}$ THF $(0.1 \mathrm{M})$ was added slowly to this refluxing solution. To this, 1 equiv. of 2-methylpropane-1,2-diamine $(0.30 \mathrm{~g}, 3.49 \mathrm{mmol})$ dissolved in $35 \mathrm{~mL}$ $\mathrm{CH}_{3} \mathrm{OH}(0.1 \mathrm{M})$ was added dropwise over a period of 4.5 hours and resulting mixture was refluxed for 30 minutes. The resulting yellow colored solution was cooled down to room temperature and solvent was removed in vacuo to yield a sticky crude product which after triturating with diethyl ether gave a yellow solid. Vapor diffusion of diethyl ether into a smaller concentrated $\mathrm{CH}_{3} \mathrm{CN}$ solution of $\left[\mathrm{H}_{2} \mathrm{Ba}\right]$ was used to obtain single crystals suitable $\mathrm{f}$ or $\mathrm{X}$-ray diffraction studies.

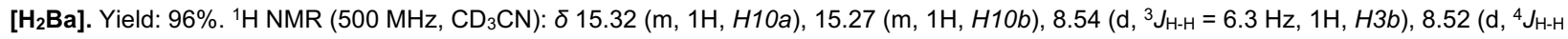
$=3.0 \mathrm{~Hz}, 1 \mathrm{H}, H 3 a), 7.08\left(\mathrm{~d},{ }^{3} \mathrm{~J}_{\mathrm{H}-\mathrm{H}}=7.9 \mathrm{~Hz}, 3 \mathrm{H}, \mathrm{H} 4\right.$ and H6), $7.03\left(\mathrm{dd},{ }^{3} \mathrm{JH}_{\mathrm{H}-\mathrm{H}}=7.8,{ }^{4} \mathrm{~J}_{\mathrm{H}-\mathrm{H}}=1.5 \mathrm{~Hz}, 1 \mathrm{H}, H 4\right), 6.74\left(\mathrm{t},{ }^{3} \mathrm{JH}-\mathrm{H}=7.9 \mathrm{~Hz}, 1 \mathrm{H}, \mathrm{H5}\right), 6.63$ (t, $\left.{ }^{3} \mathrm{~J}_{\mathrm{H}-\mathrm{H}}=7.9 \mathrm{~Hz}, 1 \mathrm{H}, H 5\right), 4.26(\mathrm{~m}, 4 \mathrm{H}, H 7), 4.01(\mathrm{~m}, 4 \mathrm{H}, H 8), 3.88(\mathrm{~s}, 4 \mathrm{H}, H 9), 3.83\left(\mathrm{~d},{ }^{4} \mathrm{~J}_{\mathrm{H}-\mathrm{H}}=3.9 \mathrm{~Hz}, 2 \mathrm{H}, H 2\right), 1.49(\mathrm{~s}, 6 \mathrm{H}, H 1) \mathrm{ppm} .{ }^{13} \mathrm{C}$ $\operatorname{NMR}\left(126 \mathrm{MHz}, \mathrm{CD}_{3} \mathrm{CN}\right.$ ): $\delta 169.74$ (C3a), 165.62, 164.48 (C3b), 161.59, 150.81, 149.72, 126.78, 126.00, 123.21, 120.66, 117.07 (C5), 116.50, 116.23, 115.99, 115.56, 115.34 (C5), 71.56 (C9), 71.48 (C9), 70.49 (C8), 70.36 (C8), 67.94 (C7), 67.76 (C7), 64.94 (C2), $60.35,24.15$ (C1) ppm. ${ }^{19} \mathrm{~F}$ NMR (471 MHz, $\left.\mathrm{CD}_{3} \mathrm{CN}\right): \delta-80.13$ ppm. Anal. Calcd for $\mathrm{C}_{26} \mathrm{H}_{30} \mathrm{~N}_{2} \mathrm{O}_{12} \mathrm{~F}_{6} \mathrm{~S}_{2} \mathrm{Ba}\left(\left[\mathrm{H}_{2} \mathrm{Ba}\right]\right)$ : C 35.57, H 3.44, N 3.19; Found: C 35.55, H $3.15, N 3.25$.

Synthesis of [Pd]. To a suspension of $\left[\mathrm{H}_{2} \mathrm{Ba}\right](1.17 \mathrm{~g}, 1.33 \mathrm{mmol})$ in in $\mathrm{CHCl}_{3}$ was added an excess of guanidinium sulfate (4.32 $\mathrm{g}, 19.99$ $\mathrm{mmol}$ ) dissolved in water and the resulting mixture was stirred for 36 hours. The clear yellow organic layer was separated, solvent was removed, and the concentrated solution was immediately diluted using $15-20 \mathrm{~mL} \mathrm{CH} 3 \mathrm{OH}$. To this, 0.33 equiv. solution of $\left[\mathrm{Pd}(\mathrm{OAc})_{2}\right]_{3}(0.30 \mathrm{~g}, 0.44 \mathrm{mmol})$ dissolved in $10 \mathrm{~mL}$ of $\mathrm{CH}_{3} \mathrm{OH}$ was added slowly and the mixture was allowed to stir at room temperature. After 1 hour, an olive-green precipitate had formed, which was filtered and washed with cold diethyl ether to yield a dark greenish yellow solid. Dark yellow colored single-crystals suitable for X-ray diffraction studies were obtained by vapor diffusion of diethyl ether into a concentrated solution of [Pd] in dichloromethane.

[Pd]. Yield: $78 \% .{ }^{1} \mathrm{H}$ NMR $\left(500 \mathrm{MHz}, \mathrm{CD}_{3} \mathrm{CN}\right): \delta 7.94(\mathrm{~s}, 1 \mathrm{H}, H 3 b), 7.89\left(\mathrm{t},{ }^{4} \mathrm{~J}-\mathrm{H}=1.5 \mathrm{~Hz}, 1 \mathrm{H}, H 3 a\right), 7.01\left(\mathrm{dd},{ }^{3} \mathrm{JH}_{\mathrm{H}}=8.1,{ }^{4} \mathrm{~J}-\mathrm{H}=1.6 \mathrm{~Hz}, 1 \mathrm{H}\right.$, $H 4 b), 6.93\left(\mathrm{dd},{ }^{3} \mathrm{~J}_{\mathrm{H}-\mathrm{H}}=8.1,{ }^{4} \mathrm{~J}-\mathrm{H}=1.5 \mathrm{~Hz}, 1 \mathrm{H}, \mathrm{H} 4 \mathrm{a}\right), 6.86\left(\mathrm{dt},{ }^{3} \mathrm{JH}-\mathrm{H}=7.6,5{ }_{\mathrm{H}-\mathrm{H}}=1.8 \mathrm{~Hz}, 2 \mathrm{H}, H 6\right), 6.49\left(2 \mathrm{t},{ }^{3} \mathrm{JH}_{\mathrm{H}-\mathrm{H}}=7.8 \mathrm{~Hz}, 2 \mathrm{H}, H 5\right), 4.04(\mathrm{~m}$, $4 \mathrm{H}, H 7), 3.77(\mathrm{~m}, 4 \mathrm{H}, H 8), 3.70\left(\mathrm{~d},{ }^{4} \mathrm{~J}_{\mathrm{H}-\mathrm{H}}=1.5 \mathrm{~Hz}, 2 \mathrm{H}, \mathrm{H} 2\right), 3.69(\mathrm{~s}, 4 \mathrm{H}, H 9), 1.54(\mathrm{~s}, 6 \mathrm{H}, H 1) \mathrm{ppm} .{ }^{13} \mathrm{C}\left\{{ }^{1} \mathrm{H}\right\} \mathrm{NMR}\left(126 \mathrm{MHz}, \mathrm{CD}{ }_{3} \mathrm{CN}\right): \delta 160.88$ (C3a), 157.77 (C3b), 151.67, 127.03 (C4b), 126.46 (C4a), 121.85, 121.67, 114.99 (C6), 114.96 (C6), 114.47 (C5), 114.44 (C5), 72.91 (C2), 71.22 (C9), 70.28 (C8), 70.17 (C8), 67.89 (C7), 67.85 (C7), 25.48 (C1) ppm. Electronic absorption spectrum ( $\mathrm{CH}_{3} \mathrm{CN}$ ): 253 (36600), 289 (16500), 322 (8700), $413(5900) \mathrm{nm}\left(\mathrm{M}^{-1} \mathrm{~cm}^{-1}\right)$. Cyclic Voltammetry $\left(0.1 \mathrm{M}\left[{ }^{\mathrm{n} B u} 4 \mathrm{~N}\right]^{+}[\mathrm{PF}]^{-}\right.$in $\left.\mathrm{CH} 3 \mathrm{CN}\right): E_{\mathrm{p}, \mathrm{c}}=-2.40 \mathrm{~V}$ vs Fc ${ }^{+/ 0}$. Anal. Calcd for $\mathrm{C}_{24} \mathrm{H}_{28} \mathrm{~N}_{2} \mathrm{O}_{6} \mathrm{Pd}$ ([Pd]): C 52.71, H 5.16, N 5.12; Found: C 52.59, H 4.99, N 4.92.

Synthesis of $[\mathrm{Pd}, \mathrm{M}]$. To a heterogeneous solution of $[\mathrm{Pd}]$ in $\mathrm{CH}_{3} \mathrm{CN}$ was added a 1 equiv. solution of corresponding metal triflate salt solution in $\mathrm{CH}_{3} \mathrm{CN}$ under an inert atmosphere of $\mathrm{N}_{2}$ and the resulting mixture was stirred for 2-3 hours. Depending on the identity of the metal triflate salt, color of the reaction mixture changed from dark greenish yellow to dark yellow, pale yellow or pale white as a function of increasing Lewis acidity. In vacuo removal of solvent gave the desired product in yields ranging from $80-95 \%$. Single-crystals suitable for $X$-ray diffraction studies were grown by slow vapor diffusion of diethyl ether into a concentrated $\mathrm{CH}_{3} \mathrm{CN}$ solution of $[\mathrm{Pd}, \mathrm{M}]$ complexes for $[\mathbf{P d}, \mathrm{K}],[\mathbf{P d}, \mathbf{N a}],[\mathbf{P d}, \mathbf{Y}]$ and $[\mathbf{P d}, \mathrm{Lu}]$. For $[\mathrm{Pd}, \mathrm{Sr}]$ and $[\mathrm{Pd}, \mathrm{Ca}]$, the single-crystals were obtained by vapor diffusion of diethyl ether into $\mathrm{CH}_{3} \mathrm{OH}$ solution stored outside the glovebox. 
[Pd,K]. Yield: 84\%. ${ }^{1} \mathrm{H}$ NMR (500 MHz, CD $\left.3 \mathrm{CN}\right): \delta 7.98(\mathrm{~s}, 1 \mathrm{H}, H 3 b), 7.93\left(\mathrm{t},{ }^{4} \mathrm{~J}_{\mathrm{H}-\mathrm{H}}=1.6 \mathrm{~Hz}, 1 \mathrm{H}, H 3 a\right), 7.09\left(\mathrm{dd},{ }^{3} \mathrm{JH}_{\mathrm{H}-\mathrm{H}}=8.2,{ }^{4} \mathrm{~J}_{\mathrm{H}-\mathrm{H}}=1.5 \mathrm{~Hz}, 1 \mathrm{H}\right.$, $H 4 b), 7.01\left(\mathrm{dd},{ }^{3} \mathrm{~J}_{\mathrm{H}-\mathrm{H}}=8.1,{ }^{4} \mathrm{~J}_{\mathrm{H}-\mathrm{H}}=1.5 \mathrm{~Hz}, 1 \mathrm{H}, \mathrm{H} 4 \mathrm{a}\right), 6.97\left(\mathrm{~d},{ }^{3} \mathrm{~J}_{\mathrm{H}-\mathrm{H}}=7.8,2 \mathrm{H}, H 6\right), 6.61\left(2 \mathrm{t},{ }^{3} \mathrm{~J}_{\mathrm{H}-\mathrm{H}}=7.9 \mathrm{~Hz}, 2 \mathrm{H}, H 5\right), 4.14(\mathrm{~m}, 4 \mathrm{H}, H 7), 3.87-$ $3.84(\mathrm{~m}, 4 \mathrm{H}, \mathrm{H} 8), 3.75(\mathrm{~s}, 4 \mathrm{H}, H 9), 3.74\left(\mathrm{~d},{ }^{4} \mathrm{~J}_{\mathrm{H}-\mathrm{H}}=1.5 \mathrm{~Hz}, 2 \mathrm{H}, \mathrm{H} 2\right), 1.54(\mathrm{~s}, 6 \mathrm{H}, H 1) \mathrm{ppm} .{ }^{13} \mathrm{C} \mathrm{NMR}\left(126 \mathrm{MHz}, \mathrm{CD}_{3} \mathrm{CN}\right): \delta 161.39(\mathrm{C} 3 a), 158.30$ (C3b), 155.66, 155.16, 150.69, 150.57, 127.63 (C4b), 127.10 (C4b), 122.02, 121.85, 115.68 (C5), 115.65 (C5), 115.13 (C6), 115.10 (C6), 72.77 (C2), 71.14 (C9), 70.97 (C9), 70.06 (C8), 67.54 (C7), 25.43 (C1) ppm. ${ }^{19} \mathrm{~F} \mathrm{NMR}\left(471 \mathrm{MHz}, \mathrm{CD}_{3} \mathrm{CN}\right): \delta-80.19$ ppm. Electronic absorption

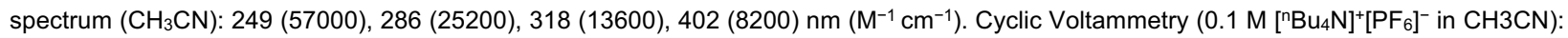
$E_{p, c}=-2.24 \mathrm{~V}$ vs $\mathrm{Fc}^{+/ 0}$. Anal. Calcd for $\mathrm{C}_{25} \mathrm{H}_{28} \mathrm{~N}_{2} \mathrm{O}_{9} \mathrm{~F}_{3} \mathrm{SPdK}$ ([Pd,K]): C 40.85, H 3.84, N 3.81; Found: C 40.38, H 3.77, N 3.76. Calcd for $\mathrm{C}_{25} \mathrm{H}_{28} \mathrm{~N}_{2} \mathrm{O}_{9} \mathrm{~F}_{3} \mathrm{SPdK}+0.5 \mathrm{H}_{2} \mathrm{O}: \mathrm{C} 40.35, \mathrm{H} 3.93, \mathrm{~N} 3.76$. This analysis is consistent with the incorporation of 0.5 equiv. of $\mathrm{H}_{2} \mathrm{O}$ during sample transport and handling.

[Pd,Na]. Yield: 82\%. ${ }^{1} \mathrm{H}$ NMR $\left(500 \mathrm{MHz}, \mathrm{CD}_{3} \mathrm{CN}\right): \delta 8.03(\mathrm{~s}, 1 \mathrm{H}, \mathrm{H} 3 b), 7.98\left(\mathrm{t},{ }^{4} \mathrm{~J}_{\mathrm{H}-\mathrm{H}}=1.4 \mathrm{~Hz}, 1 \mathrm{H}, \mathrm{H} 3 a\right), 7.12\left(\mathrm{dd},{ }^{3} \mathrm{~J}_{\mathrm{H}-\mathrm{H}}=8.2,{ }^{4} \mathrm{~J}_{\mathrm{H}-\mathrm{H}}=1.5 \mathrm{~Hz}\right.$, $1 \mathrm{H}, H 4 b), 7.04\left(\mathrm{dd},{ }^{3} \mathrm{~J}_{\mathrm{H}-\mathrm{H}}=8.2,{ }^{4} \mathrm{~J}_{\mathrm{H}-\mathrm{H}}=1.5 \mathrm{~Hz}, 1 \mathrm{H}, \mathrm{H} 4 \mathrm{a}\right), 6.98\left(\mathrm{~d},{ }^{3} \mathrm{~J}_{\mathrm{H}-\mathrm{H}}=7.6 \mathrm{~Hz}, 2 \mathrm{H}, H 6\right), 6.64\left(2 \mathrm{t},{ }^{3} \mathrm{~J}_{\mathrm{H}-\mathrm{H}}=8.0 \mathrm{~Hz}, 2 \mathrm{H}, H 5\right), 4.10\left(\mathrm{t},{ }^{3} \mathrm{JH}_{\mathrm{H}-\mathrm{H}}=4.6\right.$ $\mathrm{Hz}, 4 \mathrm{H}, H 7), 3.85\left(\mathrm{t},{ }^{3} \mathrm{H}_{\mathrm{H}-\mathrm{H}}=4.7 \mathrm{~Hz}, 4 \mathrm{H}, H 8\right), 3.77\left(\mathrm{~d},{ }^{4} \mathrm{~J}_{\mathrm{H}-\mathrm{H}}=1.4 \mathrm{~Hz}, 2 \mathrm{H}, H 2\right), 3.74(\mathrm{~s}, 4 \mathrm{H}, H 9), 1.56(\mathrm{~s}, 6 \mathrm{H}, H 1) \mathrm{ppm} .{ }^{13} \mathrm{C} \mathrm{NMR}(126 \mathrm{MHz}$, $\mathrm{CD}_{3} \mathrm{CN}$ ): $\delta 161.45$ (C3a), 158.39 (C3b), 155.41, 154.92, 150.54, 150.42, 127.62(C4b), 127.09 (C4a), 122.03, 121.85, 115.85 (C5), 115.81 (C5), 115.32 (C6), 72.59 (C2), 70.81 (C9), 70.78 (C9), 69.48 (C8), 67.57 (C1), 25.46 (C1) ppm. ${ }^{19} \mathrm{~F}$ NMR (471 MHz, CD $\left.{ }_{3} \mathrm{CN}\right): \delta-80.18$ ppm.

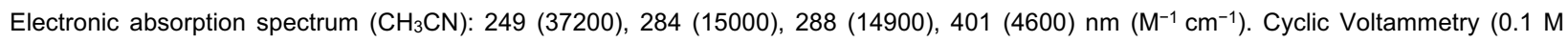

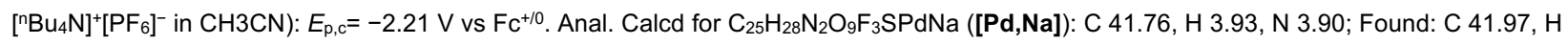
$4.01, \mathrm{~N} 3.88$.

[Pd,Sr]. Yield: 92\%. ${ }^{1} \mathrm{H}$ NMR (500 MHz, CD $\left.3 \mathrm{CN}\right): \delta 8.10(\mathrm{~s}, 1 \mathrm{H}, H 3 b), 8.06\left(\mathrm{t},{ }^{4} \mathrm{~J}-\mathrm{H}=1.7 \mathrm{~Hz}, 1 \mathrm{H}, H 3 a\right), 7.26\left(\mathrm{dd},{ }^{3} \mathrm{JH}_{\mathrm{H}-\mathrm{H}}=8.2,{ }^{4} \mathrm{~J}_{\mathrm{H}-\mathrm{H}}=1.5 \mathrm{~Hz}\right.$, $1 \mathrm{H}, H 4 b), 7.17(\mathrm{~m}, 3 \mathrm{H}, \mathrm{H} 4 \mathrm{a}$ and $H 6), 6.81\left(2 \mathrm{t},{ }^{3} \mathrm{JH}-\mathrm{H}=8.0 \mathrm{~Hz}, 2 \mathrm{H}, \mathrm{H5}\right), 4.31(\mathrm{~m}, 4 \mathrm{H}, H 7), 4.06(\mathrm{~m}, 4 \mathrm{H}, \mathrm{H8}), 3.94(\mathrm{~s}, 4 \mathrm{H}, H 9), 3.84\left(\mathrm{~d},{ }^{4} \mathrm{JH}-\mathrm{H}=1.6\right.$ $\mathrm{Hz}, 1 \mathrm{H}, \mathrm{H} 2), 1.60$ (s, 6H, H1) ppm. ${ }^{13} \mathrm{C} N M R\left(126 \mathrm{MHz}, \mathrm{CD}_{3} \mathrm{CN}\right): \delta 162.16$ (C3a), $159.04(\mathrm{C} 3 b), 152.31,151.94,149.48,149.36,128.78(C 4 b)$, 128.27 (C4a), 122.08, 121.93, 117.62 (C5), 117.58 (C5), 116.23 (C6), 116.18 (C6), 72.60, 71.77, 71.43, 70.21, 67.57, 25.32 (C1) ppm. ${ }^{19} \mathrm{~F}$ NMR (376 MHz, CD $\left.{ }_{3} \mathrm{CN}\right): \delta-80.14$ ppm. Electronic absorption spectrum ( $\left.\mathrm{CH}_{3} \mathrm{CN}\right): 243$ (42500), 280 (19000), 309 (13000), $382(6700) \mathrm{nm}\left(\mathrm{M}^{-1}\right.$ $\mathrm{cm}^{-1}$ ). Cyclic Voltammetry $\left(0.1 \mathrm{M}\left[{ }^{\mathrm{nBu}} \mathrm{Nu}_{4}\right]^{+}\left[\mathrm{PF}_{6}\right]^{-}\right.$in $\left.\mathrm{CH} 3 \mathrm{CN}\right)$ : $E_{\mathrm{p}, \mathrm{c}}=-2.06 \mathrm{~V}$ vs $\mathrm{Fc}^{+/ 0}$. Anal. Calcd for $\mathrm{C}_{26} \mathrm{H}_{28} \mathrm{~N}_{2} \mathrm{O}_{12} \mathrm{~F}_{6} \mathrm{~S}_{2} \mathrm{PdSr}([\mathrm{Pd}, \mathrm{Sr}]): \mathrm{C} 33.48$, H 3.03, N 3.00; Found: C 33.39, H 2.95, N 3.08 .

[Pd,Ca]. Yield: $88 \% .{ }^{1} \mathrm{H}$ NMR $\left(500 \mathrm{MHz}, \mathrm{CD}_{3} \mathrm{CN}\right): \delta 8.10(\mathrm{~s}, 1 \mathrm{H}, \mathrm{H3b}), 8.07\left(\mathrm{t},{ }^{4} \mathrm{~J}_{\mathrm{H}-\mathrm{H}}=1.9 \mathrm{~Hz}, 1 \mathrm{H}, \mathrm{H} 3 \mathrm{a}\right), 7.26\left(\mathrm{dd},{ }^{3} \mathrm{~J} \mathrm{H}-\mathrm{H}=8.1,{ }^{4} \mathrm{~J}-\mathrm{H}=1.4 \mathrm{~Hz}\right.$, $1 \mathrm{H}, H 4 b), 7.18\left(\mathrm{dd},{ }^{3} \mathrm{JH}_{\mathrm{H}-\mathrm{H}}=8.3,{ }^{4} \mathrm{~J}_{\mathrm{H}-\mathrm{H}}=1.5 \mathrm{~Hz}, 1 \mathrm{H}, \mathrm{H} 4 \mathrm{a}\right), 7.15\left(\mathrm{~d},{ }^{3} \mathrm{~J}_{\mathrm{H}-\mathrm{H}}=7.9 \mathrm{~Hz}, 2 \mathrm{H}, \mathrm{H6}\right), 6.83\left(2 \mathrm{t},{ }^{3} \mathrm{JH}-\mathrm{H}=8.0,2 \mathrm{H}, H 5\right), 4.27\left(\mathrm{t},{ }^{3} \mathrm{~J}-\mathrm{H}=5.3 \mathrm{~Hz}\right.$, $4 \mathrm{H}, H 7), 4.10\left(\mathrm{t},{ }^{3} \mathrm{~J}_{\mathrm{H}-\mathrm{H}}=5.4 \mathrm{~Hz}, 4 \mathrm{H}, H 8\right), 3.97(\mathrm{~s}, 4 \mathrm{H}, H 9), 3.84\left(\mathrm{~d},{ }^{4} \mathrm{~J}_{\mathrm{H}-\mathrm{H}}=1.5 \mathrm{~Hz}, 2 \mathrm{H}, H 2\right), 1.59(\mathrm{~s}, 6 \mathrm{H}, H 1) \mathrm{ppm} .{ }^{13} \mathrm{C} \mathrm{NMR}\left(126 \mathrm{MHz}, \mathrm{CD}{ }_{3} \mathrm{CN}\right):$ $\delta 162.12$ (C3a), 159.00 (C3b), 151.78, 151.34, 149.29, 149.18, 128.66 (C4b), 128.14 (C4a), 121.99, 121.82, 117.91 (C5), 117.87 (C5), 116.13 (C6), 116.10 (C6), 72.38 (C2), 71.76 (C9), 71.22 (C9), 69.67 (C8), $67.53(C 7), 67.48(C 7), 25.29(C 1)$ ppm. ${ }^{19} \mathrm{~F} \mathrm{NMR}\left(471 \mathrm{MHz}, \mathrm{CD}_{3} \mathrm{CN}\right): \delta$ -

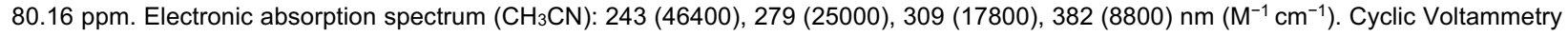
(0.1 M [ $\left.{ }^{n} \mathrm{Bu}_{4} \mathrm{~N}\right]^{+}\left[\mathrm{PF}_{6}\right]^{-}$in $\left.\mathrm{CH} 3 \mathrm{CN}\right): E_{p, c}=-2.05 \mathrm{~V}$ vs Fc ${ }^{+/ 0}$. Anal. Calcd for $\mathrm{C}_{26} \mathrm{H}_{28} \mathrm{~N}_{2} \mathrm{O}_{12} \mathrm{~F}_{6} \mathrm{~S}_{2} \mathrm{PdCa}$ ([Pd,Ca]): C 35.28, H 3.19, N 3.16; Found: C 34.05, H 3.03, N 3.34. Calcd for $\mathrm{C}_{26} \mathrm{H}_{28} \mathrm{~N}_{2} \mathrm{O}_{12} \mathrm{~F}_{6} \mathrm{~S}_{2} \mathrm{PdCa}+1.5 \mathrm{H}_{2} \mathrm{O}: \mathrm{C} 34.24, \mathrm{H} 3.43, \mathrm{~N} 3.07$. This analysis is consistent with the with the incorporation of 1.5 equiv. of $\mathrm{H}_{2} \mathrm{O}$ during the sample transport and handling.

[Pd,La]. Yield: $87 \%$. ${ }^{1} \mathrm{H}$ NMR $\left(500 \mathrm{MHz}, \mathrm{CD}_{3} \mathrm{CN}\right): \delta 8.11(2 \mathrm{~s}, 2 \mathrm{H}, H 3 \mathrm{a}$ and $H 3 b), 7.37\left(\mathrm{~d},{ }^{3} \mathrm{~J}_{\mathrm{H}-\mathrm{H}}=8.0 \mathrm{~Hz}, 1 \mathrm{H}, H 4\right), 7.30(\mathrm{~s}, 1 \mathrm{H} . H 4), 7.28\left(\mathrm{~d},{ }^{3} \mathrm{~J}-\right.$ $\mathrm{H}=8.1 \mathrm{~Hz}, 2 \mathrm{H}, H 6), 6.95\left(2 \mathrm{t},{ }^{3} \mathrm{~J} \mathrm{H}-\mathrm{H}=7.9 \mathrm{~Hz}, 2 \mathrm{H}, H 5\right), 4.52(\mathrm{~m}, 4 \mathrm{H}, H 7), 4.25(\mathrm{~m}, 4 \mathrm{H}, H 8), 4.17(\mathrm{~s}, 4 \mathrm{H}, H 9), 3.83(\mathrm{~s}, 2 \mathrm{H}, H 2), 1.60(\mathrm{~s}, 6 \mathrm{H}, H 1)$ ppm. ${ }^{13} \mathrm{C}$ NMR (126 MHz, $\left.\mathrm{CD}_{3} \mathrm{CN}\right): \delta 162.47$ (C3), 159.18 (C3), 150.41, 149.94, 149.46, 149.32, $129.82(C 4 b), 129.38$ (C4a), 122.52, 121.88 , 121.77, 120.05, 119.32 (C5), 117.76 (C6), 117.70 (C6), 72.76 (C9), 72.62 (C9), 72.27, 72.12, 71.63 (C8), 71.52(C8), 69.12 (C7), 69.02 (C7), 24.98 (C1) ppm. ${ }^{19} \mathrm{~F}$ NMR (471 MHz, $\left.\mathrm{CD}_{3} \mathrm{CN}\right): \delta-79.94$ ppm. Electronic absorption spectrum $\left(\mathrm{CH}_{3} \mathrm{CN}\right): 242(34800), 280$ (18900), 306 (15000),

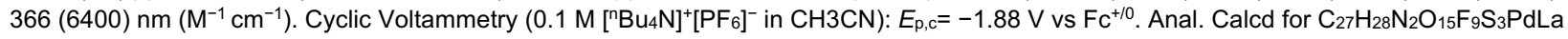
([Pd,La]): C 28.62, H 2.49, N 2.47; Found: C 30.39, H 3.01, N 2.42. Calcd for $\mathrm{C}_{26} \mathrm{H}_{28} \mathrm{~N}_{2} \mathrm{O}_{12} \mathrm{~F}_{6} \mathrm{~S}_{2} \mathrm{PdCa}+2 \mathrm{Et} 2 \mathrm{O}$ : C 30.39, H 3.29, N 2.29. This analysis is consistent with the observation of $\mathrm{Et}_{2} \mathrm{O}$ in the ${ }^{1} \mathrm{H}$ NMR spectra (see SI, Figure S32) for [Pd,La], which was incorporated during crystallization of the compound.

[Pd,Y]. Yield: 93\%. ${ }^{1} \mathrm{H}$ NMR (500 MHz, $\left.\mathrm{CD}_{3} \mathrm{CN}\right): \delta 8.14(\mathrm{~s}, 1 \mathrm{H}, \mathrm{H} 3 b), 8.12\left(\mathrm{t},{ }^{4} \mathrm{~J}_{\mathrm{H}-\mathrm{H}}=1.6 \mathrm{~Hz}, 1 \mathrm{H}, H 3 a\right), 7.40\left(\mathrm{dd},{ }^{3} \mathrm{~J}_{\mathrm{H}-\mathrm{H}}=8.2,{ }^{4} \mathrm{~J}-\mathrm{H}=1.3 \mathrm{~Hz}, 1 \mathrm{H}\right.$, $\mathrm{H} 4 b), 7.33\left(\mathrm{dd},{ }^{3} \mathrm{~J}_{\mathrm{H}-\mathrm{H}}=3.3,{ }^{4} \mathrm{~J}_{\mathrm{H}-\mathrm{H}}=1.3 \mathrm{~Hz}, 1 \mathrm{H}, \mathrm{H} 4 \mathrm{a}\right), 7.31(\mathrm{~m}, 2 \mathrm{H}, \mathrm{H} 6), 7.00\left(2 \mathrm{t},{ }^{3} \mathrm{~J}_{\mathrm{H}-\mathrm{H}}=8.0 \mathrm{~Hz}, 2 \mathrm{H}, \mathrm{H} 5\right), 4.51(\mathrm{~m}, 4 \mathrm{H}, H 7), 4.36(\mathrm{~m}, 4 \mathrm{H}, \mathrm{H} 8)$, $4.27(\mathrm{~m}, \mathrm{~J}=8.8, H 9), 3.86\left(\mathrm{~d},{ }^{4} \mathrm{~J}_{\mathrm{H}-\mathrm{H}}=1.6 \mathrm{~Hz}, 2 \mathrm{H}, \mathrm{H} 2\right), 1.62(\mathrm{~s}, 6 \mathrm{H}, \mathrm{H} 1) \mathrm{ppm} .{ }^{13} \mathrm{C} \mathrm{NMR}\left(126 \mathrm{MHz}, \mathrm{CD}_{3} \mathrm{CN}\right): \delta 162.54(\mathrm{C} 3 a), 159.39(\mathrm{C} 3 b)$, $149.15,148.65,148.35,148.15,129.64$ (C4b), 129.27 (C4a), 122.39, 122.08, 120.16, 119.84, 117.64, 72.75, 72.36, 71.93, 71.83, 71.76, 71.48, 67.98, 67.91, 24.93 (C1) ppm. $\left.{ }^{19} \mathrm{~F} \mathrm{NMR} \mathrm{(471} \mathrm{MHz,} \mathrm{CD}_{3} \mathrm{CN}\right): \delta-80.04 \mathrm{ppm}$. Electronic absorption spectrum ( $\left.\mathrm{CH}_{3} \mathrm{CN}\right): 242(24700), 278(15200)$,

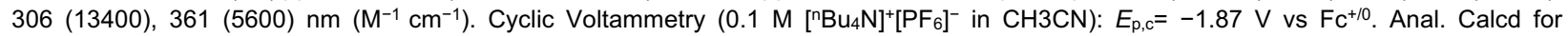
$\mathrm{C}_{27} \mathrm{H}_{28} \mathrm{~N}_{2} \mathrm{O}_{15} \mathrm{~F}_{9} \mathrm{~S}_{3} \mathrm{PdY}$ ([Pd,Y]): C 29.94, H 2.61, N 2.59; Found: C 30.27, H 2.71, N 2.20.

[Pd,Lu]. Yield: $91 \% .{ }^{1} \mathrm{H}$ NMR (500 MHz, $\left.\mathrm{CD}_{3} \mathrm{CN}\right): \delta 8.15(\mathrm{~s}, 1 \mathrm{H}, H 3 b), 8.13\left(\mathrm{t},{ }^{4} \mathrm{JH}_{\mathrm{H}}=1.4 \mathrm{~Hz}, 1 \mathrm{H}, H 3 a\right), 7.40\left(\mathrm{dd},{ }^{3} \mathrm{~J}_{\mathrm{H}-\mathrm{H}}=8.1,{ }^{4} \mathrm{~J}_{\mathrm{H}-\mathrm{H}}=1.2 \mathrm{~Hz}\right.$, $1 \mathrm{H}, H 4 b), 7.32\left(\mathrm{dd},{ }^{3} \mathrm{~J}_{\mathrm{H}-\mathrm{H}}=8.3,{ }^{4} \mathrm{~J}_{\mathrm{H}-\mathrm{H}} 1.3 \mathrm{~Hz}, 3 \mathrm{H}, H 4 \mathrm{a}\right.$ and $\left.H 6\right), 6.99\left(2 \mathrm{t},{ }^{3} \mathrm{~J}_{\mathrm{H}-\mathrm{H}}=8.0 \mathrm{~Hz}, 2 \mathrm{H}, H 5\right), 4.50(\mathrm{~m}, 4 \mathrm{H}, H 7), 4.34\left(\mathrm{t},{ }^{3} \mathrm{JH}_{\mathrm{H}-\mathrm{H}}=4.6 \mathrm{~Hz}, 4 \mathrm{H}\right.$, H8), $4.27(\mathrm{~m}, 4 \mathrm{H}, \mathrm{H} 9), 3.87\left(\mathrm{~d},{ }^{4} \mathrm{~J}_{\mathrm{H}-\mathrm{H}}=1.4 \mathrm{~Hz}, 2 \mathrm{H}, \mathrm{H} 2\right), 1.62$ (s, 6H, H1) ppm. ${ }^{13} \mathrm{C}$ NMR (126 MHz, $\left.\mathrm{CD}_{3} \mathrm{CN}\right): \delta 162.48$ (C3a), 159.37 (C3b), $149.35,148.88,148.30,148.10,129.72$ (C4b), 129.38 (C4a), 122.77, 122.52, 122.41, 120.27, 119.98, 119.90, 117.99, 72.79, 72.23, 72.03, 
71.79, 71.75, 71.71, 68.10, 67.97, 24.93 (C1) ppm. $\left.{ }^{19} \mathrm{~F} \mathrm{NMR} \mathrm{(471} \mathrm{MHz,} \mathrm{CD}_{3} \mathrm{CN}\right): \delta-80.05 \mathrm{ppm}$. Electronic absorption spectrum (CH $\left.\mathrm{CHN}_{3}\right): 242$

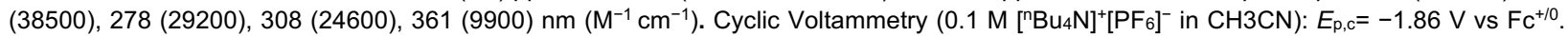
Anal. Calcd for $\mathrm{C}_{27} \mathrm{H}_{28} \mathrm{~N}_{2} \mathrm{O}_{15} \mathrm{~F}_{9} \mathrm{~S}_{3} \mathrm{PdLu}$ ([Pd,Lu]): C 27.74, H 2.41, N 2.40; Found: C 26.94, H 2.64, N 2.19. Calcd for $\mathrm{C}_{26} \mathrm{H}_{28} \mathrm{~N}_{2} \mathrm{O}_{12} \mathrm{~F}_{6} \mathrm{~S}_{2} \mathrm{PdLu}+$ $2 \mathrm{H}_{2} \mathrm{O}$ : C 26.91, H 2.68, N 2.32. This analysis is consistent with the hygroscopic nature of this complex. Incorporation of water during sample transport or handling is likely, as we find that the strongly Lewis acidic $\mathrm{Lu}^{3+}$ has a high affinity for water.

Synthesis of $\left[\mathrm{Zn}_{2}\right]$. An excess of guanidinium sulphate $(1.40 \mathrm{~g}, 6.49 \mathrm{mmol})$ dissolved in water was added to a suspension of [ $\left.\mathrm{H}_{2} \mathrm{Ba}\right](0.38 \mathrm{~g}$, $0.43 \mathrm{mmol}$ ) in $\mathrm{CHCl}_{3}$ and the mixture was stirred for 36 hours. The separation of organic layer gave a clear yellow solution which was concentrated by in vacuo solvent removal and then immediately diluted using $10-15 \mathrm{~mL} \mathrm{CH}{ }_{3} \mathrm{OH}$. To this, 1 equiv. solution of $\mathrm{Zn}(\mathrm{OAc})_{2} \cdot 2 \mathrm{H}_{2} \mathrm{O}$ $\left(95.0 \mathrm{mg}, 0.43 \mathrm{mmol}\right.$ ) dissolved in $5 \mathrm{~mL}$ of $\mathrm{CH}_{3} \mathrm{OH}$ was added and the resulting mixture was refluxed overnight. The reaction mixture was cooled to room temperature and concentrated to $2-3 \mathrm{~mL}$ by evaporating solvent on rotary evaporator. The pale white colored solid product was crashed out using diethyl ether, filtered and air dried. Vapor diffusion of diethyl ether into concentrated $\mathrm{CH}_{3} \mathrm{CN}$ solution of the title compound was implemented to obtain single crystals suitable for $\mathrm{X}$-ray diffraction studies.

[Zn ${ }_{2}$ ]. Yield: $32 \% .{ }^{1} \mathrm{H}$ NMR (500 MHz, $\left.\mathrm{CD}_{3} \mathrm{CN}\right): \delta 8.49(\mathrm{~s}, 1 \mathrm{H}, H 3 b), 8.33(\mathrm{~s}, 1 \mathrm{H}, H 3 a), 6.94(\mathrm{~m}, 2 \mathrm{H}, H 4), 6.90\left(\mathrm{~d},{ }^{3} \mathrm{H}-\mathrm{H}=8.0 \mathrm{~Hz}, 2 \mathrm{H}, H 6\right), 6.63$ $\left(2 \mathrm{t},{ }^{3} \mathrm{~J}-\mathrm{H}=7.9 \mathrm{~Hz}, 2 \mathrm{H}, H 5\right), 4.13(\mathrm{~m}, 6 \mathrm{H}), 4.05\left(\mathrm{~d},{ }^{2} \mathrm{~J}_{\mathrm{H}-\mathrm{H}}=12.1 \mathrm{~Hz}, 1 \mathrm{H}, \mathrm{H} 2\right), 3.69(\mathrm{~m}, 6 \mathrm{H}), 3.30\left(\mathrm{~d},{ }^{2} \mathrm{~J}_{\mathrm{H}-\mathrm{H}}=12.2 \mathrm{~Hz}, 1 \mathrm{H}, \mathrm{H} 2\right), 1.84(\mathrm{~s}, 6 \mathrm{H}, \mathrm{H} 10)$, 1.54 (s, 3H, H1), 1.18 (s, 3H, H1) ppm. ${ }^{13} \mathrm{C}$ NMR (126 MHz, CD 3 CN): $\delta 169.08$ (C3a), 167.87 (C3b), 128.19 (C4), 127.39 (C4), 120.48, 120.19 , 115.67 (C5), 115.46 (C5), 114.34 (C6), 114.19 (C6), 70.95, 70.91, 69.82, 69.61, 68.08, 67.85, 67.76, 60.67, 27.54 (C1), 25.98 (C1) ppm. Cyclic

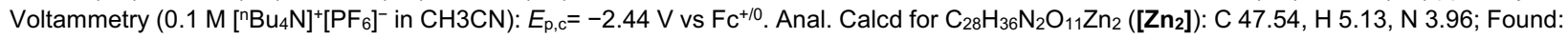
C 46.56, $\mathrm{H}$ 4.86, N 4.05. Calcd for $\mathrm{C}_{28} \mathrm{H}_{38} \mathrm{~N}_{2} \mathrm{O}_{11} \mathrm{Zn}_{2}+0.5 \mathrm{H}_{2} \mathrm{O}$ : C 46.95, $\mathrm{H} 5.21, \mathrm{~N}$ 3.91. This analysis is consistent with the hygroscopic nature of this complex and incorporation of water during sample transport or handling.

\section{X-ray crystallographic data}

CCDC entries 2056710-2056718 contain the supplementary crystallographic data for this paper. These data can be obtained free of charge from the Cambridge Crystallographic Data Centre. For details regarding collection and refinement of the data see the Supporting Information.

\section{Acknowledgements}

The authors thank Dr. Justin Douglas and Sarah Neuenswander for assistance with NMR spectroscopy. This work was supported by the US Department of Energy, Office of Science, Office of Basic Energy Sciences through the Early Career Research Program (DE-SC0019169). 


\section{References}

[1] a) A. Wu, J. Masland, R. D. Swartz, W. Kaminsky, J. M. Mayer, Inorg. Chem. 2007, 46, 11190-11201. b) D. E. Berning, B. C. Noll, D. L. DuBois, J. Am. Chem. Soc. 1999, 121, 11432-11447.

[2] a) Y. J. Park, J. W. Ziller and A. S. Borovik, J. Am. Chem. Soc. 2011, 133, 9258-9261. b) D. C. Lacy, Y. J. Park, J. W. Ziller, J. Yano and A. S. Borovik, J. Am. Chem. Soc. 2012, 134, 17526-17535. c) S. Bang, Y.-M. Lee, S. Hong, K.-B. Cho, Y. Nishida, M. S. Seo, R. Sarangi, S. Fukuzumi and W. Nam, Nat. Chem. 2014, 6, 934-940.

[3] a) T.-C. Lau, Z.-B. Wu, Z.-L. Bai and C.-K. Mak, J. Chem. Soc., Dalton Trans. 1995, 695-696. b) H. Du, P.-K. Lo, Z. Hu, H. Liang, K.-C. Lau, Y.-N. Wang, W. W. Y. Lam and T.-C. Lau, Chem. Commun. 2011, 47, 7143-7145. c) S. Lai and D. G. Lee, Tetrahedron 2002, 58, 9879-9887.

[4] a) J. S. Kanady, E. Y. Tsui, M. W. Day and T. Agapie, Science 2011, 333, 733-736. b) E. Y. Tsui and T. Agapie, Proc. Natl. Acad. Sci. U. S. A. 2013, 110, 10084-10088. c) E. Y. Tsui, J. S. Kanady and T. Agapie, Inorg. Chem. 2013, 52, $13833-13848$.

[5] a) J. P. McEvoy and G. W. Brudvig, Chem. Rev. 2006, 106, 4455-4483. b) J. Yano and V. Yachandra, Chem. Rev. 2014, 114, 4175-4205.

[6] a) B. L. Ramirez and C. C. Lu, J. Am. Chem. Soc. 2020, 142, 11, 5396-5407 b) J. P. Krogman, B. M. Foxman and C. M. Thomas, J. Am. Chem. Soc. 2011, 133, 14582-14585. c) H. Shao, S. K. Muduli, P. D. Tran and H. S. Soo, Chem. Commun. 2016, 52, 2948-2951. d) X. L. Ho, H. Shao, Y. Y. Ng, R. Ganguly, Y. Lu and H. S. Soo, Inorg. Chem. 2019, 58, 1469-1480. e) E. Solari, F. Corazza, C. Floriani, A. Chiesi-Villa and C. Guastini, J. Chem. Soc., Dalton Trans. 1990, 1345-1355. f) R. L. Meyer, M. H. Anjass, B. E. Petel, W. W. Brennessel, C. Streb and E. M. Matson, Chem. Eur. J. 2020, 26, 9905-9914.

[7] a) C. J. Van Staveren, J. Van Eerden, F. C. J. M. Van Veggel, S. Harkema and D. N. Reinhoudt, J. Am. Chem. Soc. 1988, 110, 4994-5008. b) F. C. J. M. Van Veggel, S. Harkema, M. Bos, W. Verboom, C. J. Van Staveren, G. J. Gerritsma and D. N. Reinhoudt, Inorg. Chem. 1989, 28, 1133-1148.

[8] a) P. Zanello, A. Cinquantini, P. Guerriero, S. Tamburini and P. A. Vigato, Inorg. Chim. Acta 1986, 117, 91-96. b) N. Brianese, U. Casellato, S. Tamburini, P. Tomasin and P. A. Vigato, Inorg. Chim. Acta 1999, 293, 178-194. c) P. A. Vigato and S. Tamburini, Coord. Chem. Rev. 2004, 248, 1717-2128.

[9] a) C. P. Horwitz and Y. Ciringh, Inorg. Chim. Acta 1994, 225, 191-200. b) C. P. Horwitz, Y. Ciringh and S. T. Weintraub, Inorg. Chim. Acta 1999, 294, 133-139.

[10] a) S. Matsunaga and M. Shibasaki, Synthesis 2013, 45, 421-437. b) S. Matsunaga and M. Shibasaki, Chem. Commun. 2014, 50, 1044-1057.

[11] a) A. H. Reath, J. W. Ziller, C. Tsay, A. J. Ryan and J. Y. Yang, Inorg. Chem. 2017, 56, 3713-3718. b) K. Kang, J. Fuller, A. H. Reath, J. W. Ziller, A. N. Alexandrova and J. Y. Yang, Chem. Sci. 2019, 10, 10135-10142.

[12] a) A. C. Deacy, E. Moreby, A. Phanopoulos and C. K. Williams, J. Am. Chem. Soc. 2020, 142, 19150-19160. b) W. Lindeboom, D. A. X. Fraser, C. B. Durr and C. K. Williams, Chem. Eur. J. 2021, 27, 12224-12231.

[13] A. Kumar, D. Lionetti, V. W. Day and J. D. Blakemore, J. Am. Chem. Soc. 2020, 142, 3032-3041.

[14] A. Kumar, D. Lionetti, V. W. Day and J. D. Blakemore, Chem. Eur. J. 2018, 24, 141-149.

[15] S. R. Kelsey, A. Kumar, A. G. Oliver, V. W. Day and J. D. Blakemore, ChemElectroChem 2021, 8, $2792-2802$.

[16] a) P. L. Arnold, D. Patel, C. Wilson and J. B. Love, Nature 2008, 451, 315. b) P. L. Arnold, J. B. Love and D. Patel, Coord. Chem. Rev. 2009, 253, 1973-1978. c) S. Fortier and T. W. Hayton, Coord. Chem. Rev. 2010, 254, 197-214. d) D. D. Schnaars, G. Wu and T. W. Hayton, Inorg. Chem. 2011, 50, 9642-9649.

[17] T. C. Lau and C. K. Mak, J. Chem. Soc., Chem. Commun. 1993, 766-767.

[18] S.-M. Yiu, W.-L. Man and T.-C. Lau, J. Am. Chem. Soc. 2008, 130, 10821-10827.

[19] C. J. Lata and C. M. Crudden, J. Am. Chem. Soc. 2010, 132, 131-137.

[20] S. Zhang, H. Xu, C. Lou, A. M. Senan, Z. Chen and G. Yin, Eur. J. Org. Chem. 2017, 2017, 1870-1875.

[21] a) M. R. Kita and A. J. M. Miller, J. Am. Chem. Soc. 2014, 136, 14519-14529. b) A. J. M. Miller, Dalton Trans. 2017, 46, 1198712000.

[22] J. M. Barlow, J. W. Ziller and J. Y. Yang, ACS Catal. 2021, 11, 8155-8164.

[23] N. S. Idris, J. M. Barlow, S. A. Chabolla, J. W. Ziller and J. Y. Yang, Polyhedron 2021, 208, 115385.

[24] D. D. Perrin, Ionisation Constants of Inorganic Acids and Bases in Aqueous Solution; Pergamon, 1982.

[25] R. M. Beesley, C. K. Ingold, J. F. Thorpe, J. Chem. Soc. Trans.1915, 107, 1080-1106.

[26] a) R. D. Shannon and C. T. Prewitt, Acta Cryst. 1970, B26, 1046-1048. b) R. D. Shannon, Acta Cryst. 1976, A32, $751-767$.

$\left[{ }^{27}\right]$ L. Yang, D. R. Powell and R. P. Houser, Dalton Trans., 2007, 955-964.

[28] L. Pauling, C. U. Press, M. C. i. t. H. o. Chemistry, The Nature of the Chemical Bond, and the Structure of Molecules and Crystals: An Introduction to Modern Structural Chemistry, Cornell University Press, 1940.

[29] M. Ulusoy, Ö. Birel, O. Şahin, O. Büyükgüngör, B. Cetinkaya, Polyhedron 2012, 38, 141-148.

[30] A. Kumar and J. D. Blakemore, Inorganic Chemistry 2021, 60, 1107-1115.

[31] K. M. Conner, A. C. Arostegui, D. D. Swanson and S. N. Brown, Inorg. Chem. 2018, 57, 9696-9707.

[32] a) B. Dutta, B. Adhikary, U. Florke and K. Nag, Eur. J. Inorg. Chem. 2006, 4111-4122. b) Y. Shimazaki, T. Yajima, F. Tani, S. Karasawa, K. Fukui, Y. Naruta and O. Yamauchi, J. Am. Chem. Soc. 2007, 129, 2559-2568. c) Y. Shimazaki, N. Arai, T. J. Dunn, T. Yajima, F. Tani, C. F. Ramogida and T. Storr, Dalton Trans. 2011, 40, 2469-2479. 
[33] M. Ulusoy, O. Birel, O. Sahin, O. Buyukgungor and B. Cetinkaya, Polyhedron 2012, 38, 141-148.

[34] A. J. Bard, Standard Potentials in Aqueous Solution, CRC Press, 2017.

[35] The challenge of gaining insight into reduced species is evident in work from Asakawa and co-workers that features palladiumsalophen-crown complexes as building blocks for supramolecular chemistry. ${ }^{[36 a]}$ Based on XRD evidence, the structure of a Pd(II) complex was reported as incorporating a $\mathrm{Na}^{+}$ion, and this result interpreted as isolation of a reduced species with a ligand radical. ${ }^{[36 b]}$ However, the more likely formulation of the crystallized complex is that of a neutral complex interacting with a water molecule via $\mathrm{H}$-bonding. This conclusion can be based on the reported "Na" $\cdots O \mathrm{O}$ distances (ca. $3 \AA$, consistent with $\mathrm{H}$-bonding) as well as the placement of the "Na" relative to the "coordinated" oxygens; short "Na" $\cdots \cdot \mathrm{H}$ contacts (ca. $2.8 \AA$ ) to ethylene hydrogens in the polyether chain of the crown site and an equivalent isotropic thermal parameter for "Na" that is 2-3 times higher than other atoms in the structure provide further evidence of an $\mathrm{H}$-bonded $\mathrm{H}_{2} \mathrm{O}$ interacting with the macrocyclic ligand instead of $\mathrm{Na}^{+}$. The mis-assignment of $\mathrm{Na}$ for $\mathrm{O}$ in the structure, however, was likely driven by the similar electron counts of these elements.

[36] a) I. Yoon, M. Narita, T. Shimizu and M. Asakawa, J. Am. Chem. Soc. 2004, 126, 16740-16741; b) I. Yoon, M. Goto, T. Shimizu, S. S. Lee and M. Asakawa, Dalton Trans. 2004, 1513-1515.

[37] P. Kissinger, W. R. Heineman, Laboratory Techniques in Electroanalytical Chemistry, Second Edition, Revised and Expanded, Taylor \& Francis, 1996.

[38] a) A. A. Isse, A. Gennaro and E. Vianello, Electrochim. Acta 1992, 37, 113-118. b) J. Andrez, V. Guidal, R. Scopelliti, J. Pécaut, S. Gambarelli and M. Mazzanti, J. Am. Chem. Soc. 2017, 139, 8628-8638.

[39] A. J. Bard and L. R. Faulkner, Electrochemical Methods: Fundamentals and Applications, Wiley, Hoboken, NJ, 2001.

[40] R. S. Nicholson, Anal. Chem. 1965, 37, 1351-1355.

[41] a) R. A. Marcus, N. Sutin, Biochim. Biophys Acta. - Rev. Bioenerg. 1985, 811, 265-322. b) B. S. Brunschwig, J. Logan, M. D. Newton and N. Sutin, J. Am. Chem. Soc. 1980, 102, 5798-5809.

[42] a) J. M. Savéant, C. Costentin, Elements of Molecular and Biomolecular Electrochemistry: An Electrochemical Approach to Electron Transfer Chemistry, Wiley, 2019. b) H. Y. V. Ching, E. Anxolabehere-Mallart, H. E. Colmer,C. Costentin, P. Dorlet, T. A. Jackson, C. Policar and M. Robert, Chem. Sci. 2014, 5, 2304-2310.

[43] X. Amashukeli, J. R. Winkler, H. B. Gray, N. E. Gruhn and D. L. Lichtenberger, J. Phys. Chem. A 2002, 106, 7593-7598.

[44] G. R. Fulmer, A. J. Miller, N. H. Sherden, H. E. Gottlieb, A. Nudelman, B. M. Stoltz, J. E. Bercaw, K. I. Goldberg, Organometallics 2010, 29, 2176-2179.

[45] a) R. K. Harris, E. D. Becker, S. M. C. De Menezes, R. Goodfellow, P. Granger, Pure Appl. Chem. 2001, 73, 1795-1818. b) R. K. Harris, E. D. Becker, S. M. C. De Menezes, P. Granger, R. E. Hoffman, K. W. Zilm, Pure Appl. Chem. 2008, 80, 59-84. 